\title{
Dihydromyricetin Acts as a Potential Redox Balance Mediator in Cancer Chemoprevention
}

\author{
Liang Chen, ${ }^{1,2}$ Meng Shi, ${ }^{2}$ Chenghao Lv, ${ }^{1,2}$ Ying Song, ${ }^{1,2}$ Yuanjie Wu, ${ }^{3}$ Suifei Liu, ${ }^{4}$ \\ Zhibing Zheng, ${ }^{2}$ Xiangyang Lu $\mathbb{D}^{1},{ }^{1}$ and Si Qin $\mathbb{D}^{1,2}$ \\ ${ }^{1}$ College of Bioscience and Biotechnology, Hunan Agricultural University, Changsha 410128, China \\ ${ }^{2}$ College of Food Science and Technology, Hunan Agricultural University, Changsha 410128, China \\ ${ }^{3}$ Hunan Tea Group Co., Ltd., Changsha 410128, China \\ ${ }^{4}$ Jiangxi Agricultural Engineering College, Yichun 331200, China
}

Correspondence should be addressed to Xiangyang Lu; xiangyangcn@163.com and Si Qin; qinsiman@hunau.edu.cn

Received 28 December 2020; Revised 11 February 2021; Accepted 27 February 2021; Published 12 March 2021

Academic Editor: Yaoyao Xia

Copyright (c) 2021 Liang Chen et al. This is an open access article distributed under the Creative Commons Attribution License, which permits unrestricted use, distribution, and reproduction in any medium, provided the original work is properly cited.

Dihydromyricetin (DHM) is a flavonoid extracted from the leaves and stems of the edible plant Ampelopsis grossedentata that has been used for Chinese Traditional Medicine. It has attracted considerable attention from consumers due to its beneficial properties including anticancer, antioxidative, and anti-inflammatory activities. Continuous oxidative stress caused by intracellular redox imbalance can lead to chronic inflammation, which is intimately associated with the initiation, promotion, and progression of cancer. DHM is considered a potential redox regulator for chronic disease prevention, and its biological activities are abundantly evaluated by using diverse cell and animal models. However, clinical investigations are still scanty. This review summarizes the current potential chemopreventive effects of DHM, including its properties such as anticancer, antioxidative, and antiinflammatory activities, and further discusses the underlying molecular mechanisms of DHM in cancer chemoprevention by targeting redox balance and influencing the gut microbiota.

\section{Introduction}

Ampelopsis grossedentata (A. grossedentata) is a medicinal and edible plant widely used in China as a Traditional Chinese Medicine for the treatment of cough, fever, vomiting, hepatitis, colds, chronic nephritis, polyorexia, and sore throat. Tender stems and leaves of A. grossedentata are commonly consumed as vine tea in China for centuries due to its health benefiting effects. Dihydromyricetin $\left(3,5,7,3^{\prime}, 4^{\prime}, 5^{\prime}\right.$ -hexahydroxy-2,3-dihydroflavonol (DHM)) (Figure 1), also known as ampelopsin, is a major flavonoid extracted from the leaves and stems of $A$. grossedentata. The content of DHM in A. grossedentata ranges from 30\% to $40 \%$ (dry weight), which is considered to have the highest flavonoid content in natural plants [1]. Several scientific investigations reported that DHM possesses various biological activities such as anti-inflammatory $[2,3]$, antioxidative $[4,5]$, anticancer $[6,7]$, antidiabetic $[8-10]$, antiatherosclerosis [11, $12]$, and cardioprotective effects $[13,14]$. The biological properties and the underlying mechanisms of DHM were investigated mostly by in vitro cell cultures and in vivo animal models. In addition, DHM was reported as toxicologically safe and could effectively reverse multidrug resistance [1519]. Hence, DHM is a promising bioactive compound for developing healthy/functional foods.

Despite these health-promoting effects, DHM has very poor water-solubility and aqueous stability. The solubility characteristics of DHM in cold water, hot water, and ethanol were $0.2-0.32 \mathrm{mg} / \mathrm{mL}$ at $25^{\circ} \mathrm{C}, 20 \mathrm{mg} / \mathrm{mL}$ at $80^{\circ} \mathrm{C}$, and $170 \mathrm{mg} / \mathrm{mL}$ at $25^{\circ} \mathrm{C}$, respectively [20]. DHM is more stable in acidic conditions ( $\mathrm{pH}$ range of 1.0-5.0) than in an alkaline environment. Under alkaline conditions, especially at a $\mathrm{pH}$ 
<smiles>O=C1c2c(O)cc(O)cc2O[C@H](c2cc(O)c(O)c(O)c2)[C@@H]1O</smiles>

Figure 1: Chemical structure of dihydromyricetin (DHM).

range from 6.0 to 8.0 , DHM was prone to oxidation and degraded dramatically [21]. Similarly, the stability of DHM is affected by the $\mathrm{pH}$ rather than the digestive enzymes including pepsin and pancreatin under the in vitro digestion system [21]. At a concentration of $20 \mu \mathrm{g} / \mathrm{mL}, \mathrm{DHM}$ was stable at room temperature after $12 \mathrm{~h}$ and at $-20^{\circ} \mathrm{C}$ for $10 \mathrm{~d}$, but only $45.42 \%$ was retained after $3 \mathrm{~h}$ in simulated intestinal fluid at $37^{\circ} \mathrm{C}$ [21]. The plasma DHM concentration reached maximum $(159 \mu \mathrm{g} / \mathrm{L})$ at $1.5 \mathrm{~h}$ postadministration when DHM powder was given at a dosage of $115 \mathrm{mg} / \mathrm{kg}$ body weight in rabbits, indicating a low bioavailability of DHM [18]. Efflux transporters, multidrug resistance protein 2, and breast cancer resistance protein also played an important role in DHM uptake and transport processes [22]. A research group had investigated the distribution, excretion, and metabolic profile of DHM and found that most unconverted DHM forms were excreted in feces [23]. Eight metabolites of DHM in urine and feces were found to be linked with reduction, methylation, dehydroxylation, glucuronidation, and sulfation metabolic pathways [23]. These problems together resulted in its low membrane permeability $\left(P_{\text {eff }}=(1.84 \pm 0.37) \times 10^{-6} \mathrm{~cm} / \mathrm{s}\right)$ and compromised bioavailability [18]. However, the amount of DHM from the daily intake of Ampelopsis grossedentata that can possibly exert its bioactivity had been investigated in clinical trials. For instance, the administration of DHM at $970 \mathrm{mg} /$ day was reported to effectively ameliorate the glycemic control in type 2 diabetes mellitus in a previous study [18]. In a double-blind clinical trial, daily uptake of $600 \mathrm{mg}$ of DHM exerted antiinflammatory effects on patients with nonalcoholic fatty liver disease [18].

Through identification and quantification methods, the transport mechanisms and protective effects of DHM in metabolic diseases have recently been reviewed [18, 24]; however, the anti-inflammatory, antioxidative, and anticancer effects and their underlying molecular mechanisms have not been fully documented. This study is aimed at giving an overview of the anti-inflammatory, antioxidative, and anticancer effects of DHM, as well as recent findings regarding its underlying molecular mechanisms including redox balance and the role of gut microbiota.

\section{Dihydromyricetin Exerts Its Chemopreventive Potential against Cancer}

Cancer is a public health problem and the leading cause of morbidity and mortality worldwide. The redox imbalance involving persistent chronic inflammation and reduced antioxidant capacity are the critical pathological causes of cancer. Presently, chemoprevention is a major approach to prevent the growth of cancer cells. However, high cost and side effects associated with chemotherapy have prompted scientists to search for safe alternative natural compounds for cancer therapy [25]. Flavonoids are plant phytochemicals, and several epidemiological studies have reported that flavonoid intake may prevent a variety of cancers such as lung, breast, prostate, pancreas, and colon cancers [26].

DHM, a flavonoid from the edible plant Ampelopsis grossedentata, exhibited anticancer activity against a variety of cancer cells in various cultured cancer cells and animal models transplanted with cancer cells, as shown in Table 1. The most widely used cell lines for the determination of anticancer effects of DHM were HepG2 and SK-Hep-1 (human hepatocellular carcinoma), MCF-7 and MDA-MB-231 (human breast cancer), PC-3 (human prostate cancer), A549 and H1975 (human non-small-cell lung cancer), U251 and A172 (human glioma), SKOV3 (human ovarian cancer), SGC7901 and SGC7901/5-FU (human gastric carcinoma), and JAR (human choriocarcinoma) [27-39]. Different cancer cell lines were used by various researchers as each cell line has a different origin, tumor characteristics, and signaling pathways. In addition, animals such as mice and rats with transplanted cancer cells have also been used as in vivo models for investigation of antitumor activity of DHM [31, 37, 40, 41].

DHM effectively showed anticancer activity in a variety of cancers such as breast cancer, hepatocellular carcinoma, melanoma, ovarian cancer, lung cancer, cervical carcinoma, glioma, and osteosarcoma [32, 33, 42-46]. Among the treatments for different cancer cells, DHM has a broad dosage from 1 to $1000 \mu \mathrm{M}$ with a duration from 6 to $72 \mathrm{~h}$, presenting cell proliferation inhibition and apoptosis-inducing effects (Table 1). The concentration of DHM used in various studies shifts dramatically, which might be due to the differences in cell lines, DHM purity, and cell treatment conditions. The functional mechanisms and major pathways are also listed in Table 1. DHM inhibited the proliferation of HepG2 cells via G2/M phase cell cycle arrest through the Chk1/Chk2/Cdc25C signaling pathway; induced the apoptosis of HepG2 cells that target ROS-related, Akt/Bad, ERK1/2, AMPK, and PI3K/PDK1/Akt signaling pathways; enhanced the levels of DR4, DR5, Bax, Bad, and caspase 3; and reduced the expression of Bcl-2 protein and mTOR [30, 32, 47, 48]. The suppressing effect of DHM on the MDA-MB-231 breast cancer cell line was reported through ROS generation, ER stress pathway, and inhibition of mTOR [28, 31]. DHM treatment dose-dependently inhibited the growth of HeLa cells by inducing apoptosis through activation of caspases 9 and 3 and increasing the ratio of Bax protein to Bcl-2 [44]. In A549 human adenocarcinoma lung epithelial cells, DHM decreased XIAP and survivin expression levels and cleaved poly(ADP-ribose) polymerase. DHM stimulated apoptosis via a p53-mediated pathway in ovarian cancer cells A2780 and SKOV3 [46]. DHM was also reported to inhibit human melanoma SK-MEL-28 cells by inducing apoptosis; arresting cell cycle at the G1/S phases; increasing the production of $\mathrm{p} 53$ 
TABLE 1: The chemopreventive effect and potential mechanism of dihydromyricetin in cancer.

\begin{tabular}{|c|c|c|c|c|c|c|}
\hline Origin & $\begin{array}{c}\text { Cell } \\
\text { lines/animals/human }\end{array}$ & $\begin{array}{l}\text { Treatment } \\
\text { methods }\end{array}$ & $\begin{array}{c}\text { Mode of } \\
\text { administration }\end{array}$ & $\begin{array}{c}\text { Dose and } \\
\text { duration time }\end{array}$ & $\begin{array}{c}\text { Mechanism of } \\
\text { action/activities/effects } \\
\text { showed }\end{array}$ & Reference \\
\hline $\begin{array}{l}\text { DHM prepared from } \\
\text { A. grossedentata with } \\
\text { a purity of } 98 \%\end{array}$ & Osteosarcoma cells & $\begin{array}{l}\text { Cell cycle and } \\
\text { apoptosis } \\
\text { analysis }\end{array}$ & & $\begin{array}{l}15,30, \text { and } \\
60 \mu \mathrm{M} \text { for } 24 \\
\quad \text { or } 48 \mathrm{~h}\end{array}$ & $\begin{array}{l}\text { (1) Exhibited anticancer } \\
\text { activity through increased } \\
\text { p21 expression and G2-M } \\
\text { cell cycle arrest, caused } \\
\text { DNA damage, activated } \\
\text { ATM-CHK2-H2AX } \\
\text { signaling pathways, and } \\
\text { induced apoptosis in } \\
\text { osteosarcoma cells } \\
\text { (2) Antitumor could be due } \\
\text { to the activation of AMPK } \\
\text { and p38MAPK pathways }\end{array}$ & $\begin{array}{l}\text { Zhiqiang } \\
\text { et al. (2014) }\end{array}$ \\
\hline Ampelopsin $\geq 98 \%$ & $\begin{array}{l}\text { Non-small-cell lung } \\
\text { cancer (NSCLC) cells }\end{array}$ & $\begin{array}{l}\text { Cell death } \\
\text { analysis }\end{array}$ & & $\begin{array}{c}20 \mu \mathrm{M} \text { for } 48- \\
72 \mathrm{~h}\end{array}$ & $\begin{array}{l}\text { DHM in combination with } \\
\text { erlotinib induced cell death } \\
\text { via the NOX2-ROS-Bim } \\
\text { pathway in NSCLC cells }\end{array}$ & $\begin{array}{l}\text { Seung- } \\
\text { Woo et al. } \\
(2017)\end{array}$ \\
\hline $\begin{array}{l}\text { Ampelopsins A and } \\
\mathrm{C} \text { isolated from the } \\
\text { roots of } V . \text { thunbergii } \\
\text { with a purity of } 98.5 \\
\text { and } 99.0 \% \text {, } \\
\text { respectively }\end{array}$ & $\begin{array}{l}\text { MDA-MB-231 } \\
\text { breast cancer cells }\end{array}$ & $\begin{array}{l}\text { Metastasis } \\
\text { analysis }\end{array}$ & & $\begin{array}{l}\text { Ampelopsin } \\
\text { A }(10 \\
-50 \mu \mathrm{M}) \text { and } \\
\text { Ampelopsin } \\
C(1-5 \mu \mathrm{M}) \\
\text { for } 24-72 \mathrm{~h}\end{array}$ & $\begin{array}{l}\text { Inhibited metastasis of } \\
\text { MDA-MB-231 cells by } \\
\text { downregulating the AxL, } \\
\text { TYRO3, and FYN } \\
\text { expressions }\end{array}$ & $\begin{array}{l}\text { Cheng et al. } \\
\text { (2019) }\end{array}$ \\
\hline Ampelopsin $\geq 98 \%$ & $\begin{array}{l}\text { MCF-7 and MDA- } \\
\text { MB-231 breast } \\
\text { cancer cells }\end{array}$ & $\begin{array}{l}\text { Cell viability and } \\
\text { increased } \\
\text { apoptosis } \\
\text { analysis }\end{array}$ & & $\begin{array}{c}60 \mu \mathrm{M} \text { for } \\
24 \mathrm{~h}\end{array}$ & $\begin{array}{c}\text { DHM inhibited cell } \\
\text { viability and increased } \\
\text { apoptosis in MCF-7 and } \\
\text { MDA-MB-231 breast } \\
\text { cancer cells through ROS } \\
\text { generation and ER stress } \\
\text { pathway }\end{array}$ & $\begin{array}{l}\text { Yong et al. } \\
\text { (2014) }\end{array}$ \\
\hline $\begin{array}{l}\text { Ampelopsin (purity } \\
\text { not provided) }\end{array}$ & HepG2 cells & $\begin{array}{l}\text { Apoptosis } \\
\text { analysis }\end{array}$ & & $\begin{array}{l}0,12.5,25, \\
50,100,150, \\
\text { and } \\
200 \mu \mathrm{g} / \mathrm{mL} \\
\text { for } 12,24, \\
\text { and } 36 \mathrm{~h}\end{array}$ & $\begin{array}{l}\text { (1) Induced apoptosis of } \\
\text { HepG2 cells } \\
\text { (2) Enhanced the levels of } \\
\text { death receptor } 4 \text { (DR4) and } \\
\text { death receptor } 5 \text { (DR5) and } \\
\text { reduced the expression of } \\
\text { Bcl-2 protein }\end{array}$ & $\begin{array}{l}\text { Shimei } \\
\text { et al. (2015) }\end{array}$ \\
\hline Ampelopsin $\geq 98 \%$ & $\begin{array}{c}\text { A549 human } \\
\text { adenocarcinoma } \\
\text { lung epithelial cells }\end{array}$ & $\begin{array}{l}\text { Apoptosis } \\
\text { analysis }\end{array}$ & & $\begin{array}{c}0,10,20, \text { or } \\
30 \mu \mathrm{M} \text { for } \\
48 \mathrm{~h}\end{array}$ & $\begin{array}{c}\text { (1) Induced apoptosis in } \\
\text { A549 cells } \\
\text { (2) Reduced Bcl } 2 \text { and } \\
\text { increased Bax levels } \\
\text { (3) Cleaved PARP and } \\
\text { reduced XIAP and survivin } \\
\text { expression levels } \\
\text { (4) Cleaved poly(ADP- } \\
\text { ribose) polymerase } \\
\text { expression }\end{array}$ & $\begin{array}{l}\text { Xin-mei } \\
\text { et al. (2015) }\end{array}$ \\
\hline DHM $\geq 98 \%$ & $\begin{array}{c}\text { Mouse } \\
\text { hepatocellular } \\
\text { carcinoma cells } \\
\text { (Hepal-6) }\end{array}$ & $\begin{array}{l}\text { Cell viability and } \\
\text { apoptosis } \\
\text { analysis }\end{array}$ & & $\begin{array}{c}10,50, \text { or } \\
100 \mu \mathrm{M} \text { for } \\
6 \mathrm{~h}, 12 \mathrm{~h} \text {, and } \\
24 \mathrm{~h}\end{array}$ & $\begin{array}{c}\text { DHM inhibited cell } \\
\text { viability and induced } \\
\text { apoptosis by } \\
\text { downregulating ROS } \\
\text { production via the TGF } \\
\beta / \text { Smad3 signaling pathway } \\
\text { in Hepal } 6 \text { cells }\end{array}$ & $\begin{array}{l}\text { Bin et al. } \\
(2015)\end{array}$ \\
\hline $\begin{array}{l}\text { AMP extracted from } \\
\text { A. megalophylla } \\
\text { (purity not provided) }\end{array}$ & HeLa cells & $\begin{array}{l}\text { Apoptosis } \\
\text { analysis }\end{array}$ & & $\begin{array}{r}0,30,40,50, \\
60, \text { or } 70 \mu \mathrm{M} \\
\text { for } 8 \mathrm{~h} \text { or } 12 \mathrm{~h}\end{array}$ & $\begin{array}{l}\text { Induced apoptosis in HeLa } \\
\text { cells through activation of } \\
\text { caspases } 9 \text { and } 3\end{array}$ & $\begin{array}{l}\text { Peipei et al. } \\
\quad(2017)\end{array}$ \\
\hline
\end{tabular}


TABle 1: Continued.

\begin{tabular}{|c|c|c|c|c|c|c|}
\hline Origin & $\begin{array}{c}\text { Cell } \\
\text { lines/animals/human }\end{array}$ & $\begin{array}{l}\text { Treatment } \\
\text { methods }\end{array}$ & $\begin{array}{c}\text { Mode of } \\
\text { administration }\end{array}$ & $\begin{array}{c}\text { Dose and } \\
\text { duration time }\end{array}$ & $\begin{array}{c}\text { Mechanism of } \\
\text { action/activities/effects } \\
\text { showed }\end{array}$ & Reference \\
\hline $\mathrm{DHM} \geq 98 \%$ & $\begin{array}{l}\text { Hepatoma cell lines } \\
\text { SK-Hep-1 and } \\
\text { MHCC97L }\end{array}$ & $\begin{array}{c}\text { Growth } \\
\text { inhibition assays }\end{array}$ & & $\begin{array}{l}0,10,50, \text { and } \\
100 \mu \mathrm{mol} / \mathrm{L} \\
\text { for } 24 \mathrm{~h}\end{array}$ & $\begin{array}{l}\text { DHM inhibited the } \\
\text { migration and invasion of } \\
\text { hepatoma cells via reducing } \\
\text { the phosphorylation levels } \\
\text { of } \mathrm{p} 38, \text { ERK1/2, and JNK }\end{array}$ & $\begin{array}{l}\text { Qing-Yu } \\
\text { et al. (2014) }\end{array}$ \\
\hline $\begin{array}{l}\text { DHM with a purity } \\
\text { of } 95 \%\end{array}$ & HepG2 cells & $\begin{array}{l}\text { Apoptosis } \\
\text { analysis }\end{array}$ & & $\begin{array}{c}0,10,20, \text { and } \\
30 \mu \mathrm{M} \text { for } \\
24 \mathrm{~h}\end{array}$ & $\begin{array}{l}\text { (1) Inhibition of the } \\
\text { Akt/Bad signaling pathway } \\
\text { (2) Upregulated the levels } \\
\text { of mitochondrial } \\
\text { proapoptotic proteins Bax } \\
\text { and Bad } \\
\text { (3) Inhibited the expression } \\
\text { of the antiapoptotic protein } \\
\text { Bcl-2 and enhanced the } \\
\text { cleavage and activation of } \\
\text { caspase } 3 \\
\text { (4) Degradation of } \\
\text { poly(ADP-ribose) } \\
\text { polymerase }\end{array}$ & $\begin{array}{l}\text { Zhuangwei } \\
\text { et al. (2017) }\end{array}$ \\
\hline $\mathrm{DHM} \geq 98 \%$ & $\begin{array}{l}\text { Human melanoma } \\
\text { SK-MEL-28 cells }\end{array}$ & $\begin{array}{l}\text { Cell cycle and } \\
\text { apoptosis } \\
\text { analysis }\end{array}$ & & $\begin{array}{c}0,50, \text { and } \\
100 \mu \mathrm{M} \text { for } \\
24,48, \text { or } 72 \mathrm{~h}\end{array}$ & $\begin{array}{l}\text { (1) DHM inhibited cell } \\
\text { proliferation (SK-MEL-28) } \\
\text { cells through cell cycle } \\
\text { arrest at the G1/S phase } \\
\text { (2) Increased the } \\
\text { production of p53 and p21 } \\
\text { and downregulated the } \\
\text { Cdc25A, Cdc2, and P-Cdc2 } \\
\text { proteins } \\
\text { (3) Induced apoptosis } \\
\text { through enhancing the } \\
\text { expression levels of Bax } \\
\text { proteins and decreasing the } \\
\text { protein levels of IKK- } \alpha, \\
\text { NF- } \kappa \mathrm{B} \text { (p65), and P-p38 }\end{array}$ & $\begin{array}{l}\text { Guofang } \\
\text { et al. (2014) }\end{array}$ \\
\hline $\mathrm{DHM} \geq 98 \%$ & $\begin{array}{l}\text { AGS human gastric } \\
\text { cancer cells }\end{array}$ & $\begin{array}{l}\text { Cytotoxicity } \\
\text { assays }\end{array}$ & & $\begin{array}{l}25,50 \text {, and } \\
100 \mu \mathrm{M} \text { for } \\
48 \text { or } 72 \mathrm{~h}\end{array}$ & $\begin{array}{l}\text { DHM inhibited AGS cell } \\
\text { proliferation and induced } \\
\text { cell cytotoxicity through } \\
\text { the regulation of expression } \\
\text { of apoptotic genes such as } \\
\text { p53 and B-cell lymphoma-2 }\end{array}$ & $\begin{array}{l}\text { Ji et al. } \\
\text { (2015) }\end{array}$ \\
\hline $\mathrm{DHM} \geq 98 \%$ & HepG2 cells & $\begin{array}{c}\text { Cell growth } \\
\text { inhibition assays }\end{array}$ & & $\begin{array}{c}5,10,25 \text {, and } \\
50 \mu \mathrm{M} \text { for } 6 \\
12,24, \text { and } \\
48 \mathrm{~h}\end{array}$ & $\begin{array}{l}\text { DHM-induced autophagy } \\
\text { inhibited cell proliferation } \\
\text { through suppressing the } \\
\text { activation of mTOR and } \\
\text { regulating upstream } \\
\text { signaling pathways such as } \\
\text { ERK1/2, AMPK, and } \\
\text { PI3K/PDK1/Akt pathways }\end{array}$ & $\begin{array}{c}\text { Juan et al. } \\
(2014)\end{array}$ \\
\hline $\mathrm{DHM}>9 \%$ & $\begin{array}{c}\text { Human } \\
\text { choriocarcinoma cell } \\
\text { line (JAr cells) }\end{array}$ & Apoptosis assays & & $\begin{array}{c}0,40,60 \text {, and } \\
100 \mathrm{mg} / \mathrm{L} \text { for } \\
48 \mathrm{~h}\end{array}$ & $\begin{array}{l}\text { Inhibited proliferation of } \\
\text { JAr cells by inducing } \\
\text { apoptosis through } \\
\text { increasing protein } \\
\text { expression level of BCL-2 } \\
\text { associated X, and associated } \\
\text { protein, and decreased the } \\
\text { levels of BCL-2 and } \\
\text { procaspase } 3\end{array}$ & $\begin{array}{l}\text { Yanzhen } \\
\text { et al. (2018) }\end{array}$ \\
\hline
\end{tabular}


TABle 1: Continued.

\begin{tabular}{|c|c|c|c|c|c|c|}
\hline Origin & $\begin{array}{c}\text { Cell } \\
\text { lines/animals/human }\end{array}$ & $\begin{array}{l}\text { Treatment } \\
\text { methods }\end{array}$ & $\begin{array}{c}\text { Mode of } \\
\text { administration }\end{array}$ & $\begin{array}{c}\text { Dose and } \\
\text { duration time }\end{array}$ & $\begin{array}{c}\text { Mechanism of } \\
\text { action/activities/effects } \\
\text { showed }\end{array}$ & Reference \\
\hline $\begin{array}{l}\text { DHM (purity not } \\
\text { provided) }\end{array}$ & $\begin{array}{l}\text { Human ovarian } \\
\text { cancer A2780 and } \\
\text { SKOV3 cells }\end{array}$ & Apoptosis assays & & $\begin{array}{l}25,50 \text {, and } \\
100 \mu \mathrm{M} \text { for } \\
24 \text { or } 48 \mathrm{~h}\end{array}$ & $\begin{array}{l}\text { DHM inhibited the ovarian } \\
\text { cancer cells and induced } \\
\text { cell apoptosis through p53- } \\
\text { mediated downregulation } \\
\text { of survivin }\end{array}$ & $\begin{array}{l}\text { Yingqi et al. } \\
\quad(2017)\end{array}$ \\
\hline DHM $\geq 98 \%$ & $\begin{array}{c}\text { HepG2, QGY7701, } \\
\text { QGY7703, Huh 7, } \\
\text { QSG7701, } \\
\text { MHCC97L and H, } \\
\text { and SK-Hep-1 cells }\end{array}$ & $\begin{array}{c}\text { Cell proliferation } \\
\text { and apoptosis } \\
\text { assays }\end{array}$ & & $\begin{array}{l}0,50 \text {, and } \\
100 \mu \mathrm{M} \text { for } \\
24, \text { or } 48 \mathrm{~h}\end{array}$ & $\begin{array}{l}\text { (1) DHM inhibited cell } \\
\text { proliferation and induced } \\
\text { cell apoptosis in } \\
\text { hepatocellular carcinoma } \\
\text { cells } \\
\text { (2) Apoptosis was induced } \\
\text { through upregulating p53 } \\
\text { expression, and the } \\
\text { upregulation of p53 } \\
\text { increased the levels of } \\
\text { cleaved-caspase } 3 \text { protein }\end{array}$ & $\begin{array}{l}\text { Jie et al. } \\
(2014)\end{array}$ \\
\hline $\mathrm{DHM} \geq 98 \%$ & $\begin{array}{l}\text { SK-MEL-28 human } \\
\text { melanoma cells }\end{array}$ & Apoptosis & & $\begin{array}{l}25,50, \text { and } \\
100 \mu \mathrm{M} \text { for } \\
24 \mathrm{~h}\end{array}$ & $\begin{array}{l}\text { Enhanced cell death and } \\
\text { apoptosis by regulating the } \\
\text { NF- } \kappa \text { B signaling pathway }\end{array}$ & $\begin{array}{l}\text { Ding-Zhou } \\
\text { et al. (2017) }\end{array}$ \\
\hline $\mathrm{DHM} \geq 98 \%$ & $\begin{array}{l}\text { Hepatocellular } \\
\text { carcinoma cells }\end{array}$ & Apoptosis & & $\begin{array}{c}25-200 \mu \mathrm{M} \\
\text { for } 12 \text { or } 24 \mathrm{~h}\end{array}$ & $\begin{array}{l}\text { DHM with Nedaplatin } \\
\text { (NDP) inhibited growth } \\
\text { and induced apoptosis } \\
\text { through the activation of } \\
\text { the p53/Bcl-2 signaling } \\
\text { pathways }\end{array}$ & $\begin{array}{l}\text { Lianggui } \\
\text { et al. (2015) }\end{array}$ \\
\hline $\mathrm{DHM} \geq 98 \%$ & $\begin{array}{l}\text { A549 lung } \\
\text { carcinoma cells and } \\
\text { fibroblasts }\end{array}$ & $\begin{array}{l}\text { Growth } \\
\text { inhibition assays }\end{array}$ & & $\begin{array}{c}0,1,5 \text {, and } \\
10 \mu \mathrm{M} \text { for } \\
48 \mathrm{~h}\end{array}$ & $\begin{array}{l}\text { DHM inhibited the growth } \\
\text { of fibroblasts in the lung } \\
\text { cancer cells via the } \\
\text { activation of Erk1/2 and } \\
\text { Akt signaling pathways }\end{array}$ & $\begin{array}{l}\text { Kai-jie et al. } \\
\quad(2017)\end{array}$ \\
\hline DHM $\geq 98 \%$ & $\begin{array}{c}\text { Hepatocellular } \\
\text { cancer cells (HepG2 } \\
\text { and Hep3B) }\end{array}$ & $\begin{array}{c}\text { Growth } \\
\text { inhibition and } \\
\text { cell cycle assays }\end{array}$ & & $\begin{array}{l}2,10,50,100 \\
\text { and } 200 \mu \mathrm{M} \\
\quad \text { for } 48 \mathrm{~h}\end{array}$ & $\begin{array}{l}\text { Inhibited proliferation of } \\
\text { the cells via G2/M phase } \\
\text { cell cycle arrest through the } \\
\text { Chk1/Chk2/Cdc25C } \\
\text { signaling pathway }\end{array}$ & $\begin{array}{l}\text { Haili et al. } \\
\text { (2013) }\end{array}$ \\
\hline DHM > 99\% & $\begin{array}{l}\text { Human } \\
\text { choriocarcinoma } \\
\text { JAR cells }\end{array}$ & $\begin{array}{c}\text { Growth } \\
\text { inhibition and } \\
\text { cell cycle assays }\end{array}$ & & $\begin{array}{c}0,40,60, \text { and } \\
100 \mathrm{mg} / \mathrm{L} \text { for } \\
48 \mathrm{~h}\end{array}$ & $\begin{array}{l}\text { DHM inhibited the } \\
\text { proliferation of JAR cells } \\
\text { through cell cycle arrest via } \\
\text { the downregulation of } \\
\text { cyclin A1, cyclin D1, } \\
\text { SMAD3, and SMAD4 } \\
\text { expression levels }\end{array}$ & $\begin{array}{l}\text { Yanzhen } \\
\text { et al. (2020) }\end{array}$ \\
\hline DHM > 98\% & $\begin{array}{c}\text { Human ovarian } \\
\text { cancer SKOV3 cells }\end{array}$ & $\begin{array}{l}\text { Cell migration, } \\
\text { invasion, and } \\
\text { apoptosis assays }\end{array}$ & & $\begin{array}{c}80 \text { and } \\
120 \mu \mathrm{M} \text { for } \\
48 \mathrm{~h}\end{array}$ & $\begin{array}{l}\text { (1) Exhibited anticancer } \\
\text { activity by reducing cell } \\
\text { migration and invasion } \\
\text { (2) Induced cell apoptosis } \\
\text { via upregulation of cleaved- } \\
\text { caspase } 3 \text { and the Bax/Bcl-2 } \\
\text { ratio } \\
\text { (3) Inhibited GRASP65 } \\
\text { expression and the } \\
\text { regulation of the JNK/ERK } \\
\text { pathway }\end{array}$ & $\begin{array}{l}\text { Fengjie } \\
\text { et al. (2019) }\end{array}$ \\
\hline DHM 98\% & $\begin{array}{l}\text { Human non-small- } \\
\text { cell lung cancer }\end{array}$ & $\begin{array}{l}\text { Cytotoxic and } \\
\text { apoptosis assays }\end{array}$ & & $\begin{array}{c}0,50,75, \text { and } \\
100 \mu \mathrm{M} \text { for } \\
24 \mathrm{~h}\end{array}$ & $\begin{array}{l}\text { Exhibited cytotoxic effect } \\
\text { by inducing apoptosis } \\
\text { through Bcl-w suppression- }\end{array}$ & $\begin{array}{l}\text { Shang-Jyh } \\
\text { et al. (2017) }\end{array}$ \\
\hline
\end{tabular}


TABle 1: Continued.

\begin{tabular}{|c|c|c|c|c|c|c|}
\hline Origin & $\begin{array}{c}\text { Cell } \\
\text { lines/animals/human }\end{array}$ & $\begin{array}{l}\text { Treatment } \\
\text { methods }\end{array}$ & $\begin{array}{c}\text { Mode of } \\
\text { administration }\end{array}$ & $\begin{array}{c}\text { Dose and } \\
\text { duration time }\end{array}$ & $\begin{array}{c}\text { Mechanism of } \\
\text { action/activities/effects } \\
\text { showed }\end{array}$ & Reference \\
\hline $\begin{array}{l}\text { DHM (purity not } \\
\text { provided) }\end{array}$ & $\begin{array}{l}\text { Human gastric } \\
\text { carcinoma cells } \\
\text { (SGC7901 and } \\
\text { SGC7901/5-FU) }\end{array}$ & $\begin{array}{c}\text { Proliferation } \\
\text { inhibition assays }\end{array}$ & & $\begin{array}{c}1.25 \text { and } \\
2.5 \mu \mathrm{g} / \mathrm{mL} \text { for } \\
48 \mathrm{~h}\end{array}$ & $\begin{array}{l}\text { mediated mitochondrial } \\
\text { membrane depolarization, } \\
\text { caspase 9/7/3 activation, } \\
\text { and poly(ADP-ribose) } \\
\text { polymerase (PARP) } \\
\text { cleavage in A549 and } \\
\text { H1975 cells } \\
\text { Inhibited proliferation of } \\
\text { both SGC7901 and } \\
\text { SGC7901/5-FU cells } \\
\text { through the } \\
\text { downregulation of the } \\
\text { MDR1 expression }\end{array}$ & $\begin{array}{l}\text { Mingcai } \\
\text { et al. (2020) }\end{array}$ \\
\hline $\mathrm{DHM} \geq 98 \%$ & $\begin{array}{l}\text { Human } \\
\text { hepatocarcinoma } \\
\text { (HepG2) cells }\end{array}$ & Apoptosis assays & & $\begin{array}{l}10,50 \text {, and } \\
100 \mu \mathrm{M} \text { for } \\
24 \mathrm{~h}\end{array}$ & $\begin{array}{l}\text { DHM-induced apoptosis of } \\
\text { human hepatocellular } \\
\text { carcinoma cells through a } \\
\text { ROS-related pathway }\end{array}$ & $\begin{array}{l}\text { Bin et al. } \\
(2014)\end{array}$ \\
\hline $\begin{array}{l}\text { Ampelopsin (purity } \\
\text { not provided) }\end{array}$ & $\begin{array}{l}\text { Breast cancer MDA- } \\
\text { MB-231 cells and } \\
\text { rats }\end{array}$ & $\begin{array}{l}\text { MNU-induced } \\
\text { breast cancer in } \\
\text { rats }\end{array}$ & Orally fed & $\begin{array}{l}10,25,50 \mu \mathrm{M} \\
\text { for } 48 \mathrm{~h} \text { and } \\
50 \text { and } \\
100 \mathrm{mg} / \mathrm{kg} \\
\text { BW for } 18 \\
\text { weeks }\end{array}$ & $\begin{array}{l}\text { Inhibited the cancer cells } \\
\text { effectively in vitro and } \\
\text { in vivo through effectively } \\
\text { suppressing mammalian } \\
\text { target of rapamycin } \\
\text { (mTOR) activity in breast } \\
\text { cancer }\end{array}$ & $\begin{array}{c}\text { Chang et al. } \\
\text { (2014) }\end{array}$ \\
\hline $\begin{array}{l}\text { Ampelopsis isolated } \\
\text { from A. } \\
\text { grossedentata with } \\
80 \%\end{array}$ & $\begin{array}{l}\text { PC-3 human } \\
\text { prostate cancer cells } \\
\text { and mice prostate } \\
\text { cancer model }\end{array}$ & $\begin{array}{l}\text { Cell migration, } \\
\text { invasion, growth } \\
\text { inhibition, and } \\
\text { apoptosis assays }\end{array}$ & Oral gavage & $\begin{array}{c}0,25, \text { and } \\
50 \mu \mathrm{M} \text { for } \\
48 \mathrm{~h} .150 \text { and } \\
300 \mathrm{mg} / \mathrm{kg} \\
\text { BW for } 8 \\
\text { weeks }\end{array}$ & $\begin{array}{l}\text { (1) Inhibited the migration } \\
\text { and invasion of PC-3 cells } \\
\text { in vitro } \\
\text { (2) Decreased the growth of } \\
\text { PC-3 tumors and lymph } \\
\text { node and lung metastases } \\
\text { in a dose-dependent } \\
\text { manner in mice } \\
\text { (3) Exhibited anticancer } \\
\text { activity via induction of } \\
\text { apoptosis, reduction of } \\
\text { prostate tumor } \\
\text { angiogenesis, and reduction } \\
\text { of CXCR4 expression }\end{array}$ & $\begin{array}{l}\text { Feng et al. } \\
\text { (2012) }\end{array}$ \\
\hline $\begin{array}{l}\text { Ampelopsin-sodium } \\
\text { (purity not provided) }\end{array}$ & $\mathrm{BALB} / \mathrm{c}$ mice & $\begin{array}{l}\text { Mice implanted } \\
\text { with human } \\
\text { bladder } \\
\text { carcinoma EJ } \\
\text { cells and murine } \\
\text { sarcoma } 180 \\
\text { cells }\end{array}$ & $\begin{array}{c}\mathrm{IP} / \mathrm{IV} / \mathrm{II} \\
\text { administration }\end{array}$ & $\begin{array}{l}160,200, \text { and } \\
260 \mathrm{mg} / \mathrm{kg} \\
\text { BW for } 2-3 \\
\text { weeks }\end{array}$ & $\begin{array}{l}\text { DHM considerably } \\
\text { inhibited the proliferation } \\
\text { of EJ and sarcoma } 180 \text { cells } \\
\text { both in vivo and in vitro }\end{array}$ & $\begin{array}{l}\text { Baolai et al. } \\
\quad(2012)\end{array}$ \\
\hline Ampelopsin $\geq 98 \%$ & $\begin{array}{l}\text { Human glioma cell } \\
\text { lines U251 and A172, } \\
\text { and male BALB/c-nu } \\
\text { mice xenograft } \\
\text { model }\end{array}$ & $\begin{array}{l}\text { Apoptosis and } \\
\text { tumor growth } \\
\text { inhibition }\end{array}$ & $\begin{array}{l}\text { Intraperitoneal } \\
\text { administration }\end{array}$ & $\begin{array}{c}25,50, \\
100 \mu \mathrm{M} \text { for } \\
24 \mathrm{~h} \text { and } 50 \\
\text { and } \\
100 \mathrm{mg} / \mathrm{kg} \\
\text { BW for } 30 \\
\text { days }\end{array}$ & $\begin{array}{l}\text { (1) Induced apoptosis by } \\
\text { arresting at G1 and S } \\
\text { phases and autophagy } \\
\text { through potentiating ROS } \\
\text { generation and JNK } \\
\text { activation in human glioma } \\
\text { cells } \\
\text { (2) DHM activated caspase } \\
8 \text {, caspase } 9 \text {, and caspase } 3 \\
\text { contributing to PARP } \\
\text { cleavage }\end{array}$ & $\begin{array}{l}\text { Zhigang } \\
\text { et al. (2019) }\end{array}$ \\
\hline
\end{tabular}


TABLe 1: Continued.

\begin{tabular}{|c|c|c|c|c|c|c|}
\hline Origin & $\begin{array}{c}\text { Cell } \\
\text { lines/animals/human }\end{array}$ & $\begin{array}{l}\text { Treatment } \\
\text { methods }\end{array}$ & $\begin{array}{c}\text { Mode of } \\
\text { administration }\end{array}$ & $\begin{array}{c}\text { Dose and } \\
\text { duration time }\end{array}$ & $\begin{array}{c}\text { Mechanism of } \\
\text { action/activities/effects } \\
\text { showed }\end{array}$ & Reference \\
\hline DHM 98\% & $\begin{array}{l}\text { Colo-205 cells and } \\
\text { xenograft tumor } \\
\text { transplant mice }\end{array}$ & $\begin{array}{l}\text { Cell growth } \\
\text { inhibition assays }\end{array}$ & $\begin{array}{c}\text { Intragastric } \\
\text { administration }\end{array}$ & $\begin{array}{l}25,50 \text {, and } \\
100 \mathrm{mg} / \mathrm{kg} \\
\mathrm{BW} \text { for } 21 \\
\text { days }\end{array}$ & $\begin{array}{l}\text { (3) Reduced tumor growth } \\
\text { of human glioma xenograft } \\
\text { in mice } \\
\text { Inhibited the proliferation } \\
\text { and growth of Colo-205 } \\
\text { colon cancer cells } \\
\text { considerably in vivo and } \\
\text { in vitro via suppression of } \\
\text { the expression and } \\
\text { secretion of Sema4D }\end{array}$ & $\begin{array}{l}\text { Jun et al. } \\
\text { (2019) }\end{array}$ \\
\hline
\end{tabular}

and $\mathrm{p} 21$ proteins; enhancing the expression levels of Bax proteins; and decreasing the protein levels of IKK- $\alpha, N F-\kappa B$ (p65), and P-p38 [49]. In addition, DHM suppressed the glioma cell growth through enhancing apoptosis; arresting the cell cycle at the G1 and S phases; and activating caspase 8, caspase 9, and caspase 3 [37]. DHM exhibited anticancer activity in osteosarcoma cells through G2-M cell cycle arrest, DNA damage prevention, stimulation of the ATM-CHK2$\mathrm{H} 2 \mathrm{AX}$ signaling pathways, and enhancing p21 expression [50]. Zuo et al. reported that DHM suppressed the growth of human choriocarcinoma JAR cells by inducing cell cycle arrest and reducing the expression levels of cyclin A1, cyclin D1, SMAD3, and SMAD4. DHM function on other cancer cells is likely to share similar pathways. However, few studies have investigated the cytotoxic effects of DHM on normal cells. The anticancer effects should selectively inhibit the growth of the cancerous cells without damaging the normal cells. The lack of cytotoxic data on normal cells could potentially limit the use of DHM as an anticancer agent.

Several studies evaluated the anticancer effects of DHM in combination with anticancer drugs in order to overcome the drug resistance of cancerous cells. DHM in combination with nedaplatin (anticancer drug) showed a synergistic effect on the inhibition of the growth of hepatocellular carcinoma cells SMMC7721 and QGY7701, and induced apoptosis through the activation of the $\mathrm{p} 53 / \mathrm{Bcl}-2$ signaling pathways [51]. Also, DHM in combination with erlotinib significantly induced the caspase-dependent cell death in NSCLC due to a synergistic effect [43]. More importantly, interactions between DHM and other drugs and their toxicological properties need to be substantially evaluated before use as anticancer drugs since DHM has the potential to show synergy effects with drugs.

Apart from cultured cancer cell lines, many researchers determined the antitumor potential of DHM in various animal models bearing transplanted cancer cells. PC-3 tumor growth was significantly reduced by $49.2 \%$ through the administration of DHM at $300 \mathrm{mg} / \mathrm{kg} \mathrm{BW}$ in mice [27]. It was found that tumor size was significantly reduced in mice treated with DHM compared to the controls in athymic mice xenografted with MDA-MB-231 cells [31], in a nude mice xenograft model bearing the human osteosarcoma cell line U2OS/MTX, in a mice xenograft model bearing the human osteosarcoma cell line U2OS/MTX [50], and in xenograft BALB/c-nu mice transplanted with the human glioma cell line U251. Though there are some reports on the antitumor effects of DHM, there are some limitations that could hinder the advancement of DHM as an anticancer agent for human use. On the one hand, the molecular mechanism and major pathways still remain unclear. It is important to reveal the mechanism with consistency among cell models, animal models, and clinical studies. Therefore, more research is needed in animals and humans to generate reliable and consistent scientific evidence regarding the anticancer effects of DHM.

\section{Antioxidant Capacity Is the Main Reason for the Anticancer Property of DHM}

Aerobic cellular respiration generates free radicals and reactive oxygen species (ROS). The in-built antioxidant defense system protects the body from the harmful effects of free radicals. The imbalance between free radicals and the antioxidant defense system results in oxidative stress. The free radicals and ROS contain unpaired electrons in the outer shell, resulting in their instability. These unstable free radicals are highly reactive; attract electrons from other molecules; and cause oxidative damage to proteins, lipids, carbohydrates, and nucleic acids [52]. The oxidative damage inflicted upon macromolecules results in oxidative stress, which has been found to be highly associated with cancer [53].

Plant-derived flavonoids have been shown to inhibit free radicals and oxidative stress [54]. Recently, there have been many studies reporting on the antioxidant capacity of DHM. The evaluation methods, antioxidant properties, and mechanisms of DHM are shown in Table 2. Several in vitro, cell culture, and in vivo (animals) models are commonly used for the determination of the antioxidant activity of DHM, of which the most commonly used are the in vitro methods including free radical scavenging methods such as $\mathrm{DPPH}$, ABTS, oxygen radical absorption capacity (ORAC), $\mathrm{H}_{2} \mathrm{O}_{2}$ radical scavenging power, and $\mathrm{Fe}^{2+}$ chelating method and ferric reducing antioxidant power (FRAP) [5, 55-58]. Several studies documented the in vitro free radical scavenging activity of DHM. The $\mathrm{IC}_{50}$ values measured by $\mathrm{DPPH}$, ABTS, 
TABle 2: Antioxidant activities and mechanisms of the action of DHM.

\begin{tabular}{|c|c|c|c|c|c|}
\hline Origin & $\begin{array}{l}\text { In vitro/cell } \\
\text { culture }\end{array}$ & $\begin{array}{c}\text { Methods of } \\
\text { antioxidant activities } \\
\text { measure }\end{array}$ & $\begin{array}{l}\text { Dose and } \\
\text { duration time }\end{array}$ & Results & Reference \\
\hline $\mathrm{DHM} \geq 99.5 \%$ & RAW264.7 cells & $\begin{array}{l}\text { Lipopolysaccharide- } \\
\text { (LPS-) induced } \\
\text { oxidative stress }\end{array}$ & $\begin{array}{l}\text { DHM treated at } 0 \\
\text { to } 50 \mu \mathrm{g} / \mathrm{mL} \text { for } 2 \\
\text { hours }\end{array}$ & $\begin{array}{l}\text { DHM reduced LPS-induced oxidative stress } \\
\text { through inhibiting the production of } \\
\text { reactive oxygen species (ROS) and enhanced } \\
\text { the antioxidant system by activating } \\
\text { superoxide dismutase (SOD) and the } \\
\text { Nrf2/HO-1 pathway }\end{array}$ & $\begin{array}{l}\text { Xuejun } \\
\text { et al. (2018) }\end{array}$ \\
\hline $\mathrm{DHM} \geq 98 \%$ & HepG2 cells & $\begin{array}{l}\text { Reactive oxygen } \\
\text { species (ROS) }\end{array}$ & $\begin{array}{l}\text { DHM at } 10,50, \text { or } \\
100 \mathrm{mM} \text { for } 6 \mathrm{~h}, \\
12 \mathrm{~h} \text {, and } 24 \mathrm{~h}\end{array}$ & $\begin{array}{c}\text { DHM reduced ROS accumulation in a } \\
\text { concentration-dependent manner in HepG } 2 \\
\text { cells }\end{array}$ & $\begin{array}{c}\text { Bin et al. } \\
(2014)\end{array}$ \\
\hline $\begin{array}{l}\text { Ampelopsin purity } \\
95 \%\end{array}$ & In vitro assays & $\begin{array}{l}\text { DPPH, } \mathrm{ABTS}, \mathrm{H}_{2} \mathrm{O}_{2} \\
\text { and } \mathrm{O}_{2} \text { radical } \\
\text { methods }\end{array}$ & $\begin{array}{l}37^{\circ} \mathrm{C} \text { for } 15,20 \text {, } \\
\text { and } 60 \text { minutes }\end{array}$ & $\begin{array}{c}\text { DHM inhibited free radicals. } \mathrm{EC}_{50} \text { values of } \\
\text { DHM for scavenging DPPH, ABTS, } \mathrm{H}_{2} \mathrm{O}_{2} \text {, } \\
\text { and } \mathrm{O}_{2} \text { radicals were } 8.18,5.32,7.95 \text {, and } \\
7.79(\mu \mathrm{g} / \mathrm{mL}) \text {, respectively }\end{array}$ & $\begin{array}{l}\text { Xiang et al. } \\
\quad(2017)\end{array}$ \\
\hline Ampelopsin 98\% & PC12 cells & $\begin{array}{l}\text { Reactive oxygen } \\
\text { species }\end{array}$ & $\begin{array}{c}\text { Ampelopsin at } 50 \\
\text { and } 100 \mu \mathrm{M} \text { for } \\
1 \mathrm{~h}\end{array}$ & $\begin{array}{l}\text { DHM inhibited reactive oxygen species in 6- } \\
\text { OHDA stimulated PC12 cells in } \\
\text { concentration-dependent manner }\end{array}$ & $\begin{array}{l}\text { Xianjuan } \\
\text { et al. (2015) }\end{array}$ \\
\hline Ampelopsin $\geq 98 \%$ & $\begin{array}{l}\text { Glomerular } \\
\text { mesangial cells } \\
\text { (MCs) }\end{array}$ & $\begin{array}{l}\text { ROS and ROS } \\
\text { enzymes }\end{array}$ & $\begin{array}{c}\text { DHM at } 0,10,20, \\
\text { and } 40 \mu \mathrm{M} \text { for } \\
24 \mathrm{~h}\end{array}$ & $\begin{array}{l}\text { DHM inhibited the intracellular ROS } \\
\text { production and expression levels of ROS- } \\
\text { producing enzymes NADPH oxidase } 2 \\
\text { (NOX2) and NOX4 and mediated the } \\
\text { antioxidative effects through the activation } \\
\text { of Nrf2/HO-1 pathway }\end{array}$ & $\begin{array}{l}\text { Chunping } \\
\text { et al. }(2020)\end{array}$ \\
\hline Ampelopsin > 98\% & In vitro assays & $\begin{array}{l}\text { Hydroxyl and } \\
\text { superoxide radical } \\
\text { methods }\end{array}$ & $\begin{array}{l}\text { Ampelopsin } 10 \text { to } \\
100 \mu \mathrm{M} \text { for } 60 \mathrm{~min} \\
\text { and } 25^{\circ} \mathrm{C} \text { for } \\
20 \mathrm{~min}\end{array}$ & $\begin{array}{c}\text { Ampelopsin eliminated }{ }^{\bullet} \mathrm{OH} \text { and } \mathrm{O}_{2}{ }^{--} \text {in a } \\
\text { concentration-dependent manner; the } \mathrm{EC}_{50} \\
\text { values were } 29.4 \pm 4.1 \mu \mathrm{M} \text { and } 88.9 \pm 9.4 \mu \\
\mathrm{M}\end{array}$ & $\begin{array}{l}\text { Jiantao } \\
\text { et al. }(2008)\end{array}$ \\
\hline Ampelopsin > 98\% & PC12 cells & $\begin{array}{l}\text { Reactive oxygen } \\
\text { species }\end{array}$ & $\begin{array}{l}\text { Ampelopsin at } 1 \text {, } \\
5 \text {, and } 15 \mathrm{mg} / \mathrm{mL} \\
\text { for } 1 \mathrm{~h}\end{array}$ & $\begin{array}{l}\text { Inhibited the formation of reactive oxygen } \\
\text { species (ROS) and enhanced the cellular } \\
\text { antioxidant defense through activation of } \\
\text { the ERK and Akt signaling pathways in } \\
\text { PC12 cells }\end{array}$ & $\begin{array}{l}\text { Xianjuan } \\
\text { et al. (2011) }\end{array}$ \\
\hline DHM 64.7\% & In vitro assay & DPPH & $\begin{array}{l}\text { DHM at } 2,4,6,8 \\
10 \text {, and } 12 \mathrm{ppm} \\
\quad \text { for } 30 \mathrm{~min}\end{array}$ & $\begin{array}{l}\text { DHM extract inhibited DPPH radicals with } \\
\qquad \text { IC }_{50} \text { value of } 3.9 \mathrm{ppm}\end{array}$ & $\begin{array}{l}\text { Liyun et al. } \\
\quad(2015)\end{array}$ \\
\hline $\mathrm{DHM} \geq 98 \%$ & In vitro assays & DPPH and ORAC & $\begin{array}{l}\mathrm{DHM} \text { at } 12.5,25, \\
50,100,200, \text { and } \\
400 \mu \mathrm{g} / \mathrm{mL} \text { for } \\
30 \mathrm{~min}\end{array}$ & $\begin{array}{l}\text { DHM dose-dependently inhibited the } \\
\text { DPPH and ORAC radicals }\end{array}$ & $\begin{array}{l}\text { Kun et al. } \\
\text { (2019) }\end{array}$ \\
\hline $\mathrm{DHM} \geq 98 \%$ & HepG2 cells & Nrf2/Keap1 pathway & $40 \mu \mathrm{M}$ for $3-12 \mathrm{~h}$ & $\begin{array}{l}\text { Exhibited antioxidant activity by activating } \\
\text { the cellular Nrf2/Keap1 pathway }\end{array}$ & $\begin{array}{l}\text { Kun et al. } \\
(2019)\end{array}$ \\
\hline Not provided & $\begin{array}{l}\text { (HEI-OC) } 1 \\
\text { auditory cells }\end{array}$ & ROS & $\begin{array}{l}\text { DHM at } 10,100, \\
\text { and } 1000 \mu \mathrm{M} \text { for } \\
24 \mathrm{~h}\end{array}$ & $\begin{array}{l}\text { DHM inhibited ROS accumulation in HEI- } \\
\text { OC cells }\end{array}$ & $\begin{array}{l}\text { Hezhou } \\
\text { et al. }(2020)\end{array}$ \\
\hline DHM > 98\% & $\begin{array}{l}\text { B16F10 mouse } \\
\text { melanoma cells }\end{array}$ & $\begin{array}{l}\text { Reactive oxygen } \\
\text { species }\end{array}$ & $\begin{array}{l}1,25 \text {, and } 50 \mu \mathrm{M} \\
\quad \text { for } 24 \mathrm{~h}\end{array}$ & $\begin{array}{l}\text { DHM reduced intracellular reactive oxygen } \\
\text { species and reactive species (RS) levels }\end{array}$ & $\begin{array}{l}\text { Huey- } \\
\text { Chun et al. } \\
\text { (2016) }\end{array}$ \\
\hline $\mathrm{DHM}>98 \%$ & $\begin{array}{l}\text { Rat cardiac } \\
\text { fibroblasts }\end{array}$ & $\begin{array}{l}\text { Ang II-induced } \\
\text { oxidative stress }\end{array}$ & $\begin{array}{c}0-320 \mu \mathrm{M} \text { for } 4 \mathrm{~h} \\
\text { or } 80 \mu \mathrm{M} \text { for } 0- \\
24 \mathrm{~h}\end{array}$ & $\begin{array}{l}\text { DHM inhibited cellular reactive oxygen } \\
\text { species production and MDA level, and } \\
\text { enhanced the SOD activity and total } \\
\text { antioxidant capacity (T-AOC) }\end{array}$ & $\begin{array}{l}\text { Qiuyi et al. } \\
\text { (2017) }\end{array}$ \\
\hline $\mathrm{DHM} \geq 98 \%$ & In vitro assays & $\mathrm{DPPH}$ and ABTS & $\begin{array}{l}100 \mathrm{mg} / \mathrm{mL} \text { for } \\
6 \mathrm{~min} \text { or } 30 \mathrm{~min}\end{array}$ & $\begin{array}{c}\text { Cookies fortified with DHM significantly } \\
\text { enhanced the DPPH and ABTS radical } \\
\text { scavenging activities }\end{array}$ & $\begin{array}{c}\text { Jing et al. } \\
\text { (2018) }\end{array}$ \\
\hline DHM 97\% & PC12 cells & & & & \\
\hline
\end{tabular}


TABLE 2: Continued.

\begin{tabular}{|c|c|c|c|c|c|}
\hline Origin & $\begin{array}{l}\text { In vitro/cell } \\
\text { culture }\end{array}$ & $\begin{array}{c}\text { Methods of } \\
\text { antioxidant activities } \\
\text { measure }\end{array}$ & $\begin{array}{l}\text { Dose and } \\
\text { duration time }\end{array}$ & Results & Reference \\
\hline & & $\begin{array}{l}\text { Methylglyoxal- } \\
\text { (MG-) induced } \\
\text { oxidative stress in } \\
\text { PC12 cells }\end{array}$ & $\begin{array}{l}20 \text { and } 10 \mathrm{~mol} / \mathrm{L} \\
\text { for } 24 \mathrm{~h}\end{array}$ & $\begin{array}{l}\text { Inhibited the intracellular ROS and } \\
\text { modulating AMPK/GLUT4 signaling } \\
\text { pathway in PC12 cells }\end{array}$ & $\begin{array}{l}\text { Baoping } \\
\text { et al. (2014) }\end{array}$ \\
\hline DHM 95\% & In vitro assay & $\mathrm{DPPH}$ & $\begin{array}{l}0 \text { to } 50 \mu \mathrm{g} / \mathrm{mL} \text { for } \\
30 \mathrm{~min}\end{array}$ & $\begin{array}{l}\text { DHM and lecithin complex inhibited DPPH } \\
\text { radicals with } \mathrm{IC}_{50} \text { value of } 22.60 \mu \mathrm{g} / \mathrm{mL}\end{array}$ & $\begin{array}{l}\text { Benguo } \\
\text { et al. (2009) }\end{array}$ \\
\hline DHM > 98\% & $\begin{array}{c}\text { Rat } \\
\text { cardiomyocytes }\end{array}$ & $\begin{array}{l}\text { Ang II-stimulated } \\
\text { reactive oxygen } \\
\text { species in } \\
\text { cardiomyocytes }\end{array}$ & $\begin{array}{c}20,40,80 \text {, and } \\
160 \mu \mathrm{M} \text { for } 8 \mathrm{~h}, \\
12 \mathrm{~h}, 24 \mathrm{~h} \text {, or } 48 \mathrm{~h}\end{array}$ & $\begin{array}{l}\text { DHM reduced ROS generation in Ang II- } \\
\text { stimulated cardiomyocytes by increasing } \\
\text { total antioxidative capacity through } \\
\text { upregulating expression of SOD and } \\
\text { thioredoxin }\end{array}$ & $\begin{array}{l}\text { Guoliang } \\
\text { et al. (2015) }\end{array}$ \\
\hline $\begin{array}{l}\text { DHM (purity not } \\
\text { provided) }\end{array}$ & HUVECs & $\begin{array}{l}\text { Sodium } \\
\text { nitroprusside- (SNP- } \\
\text { ) induced oxidative } \\
\text { damage }\end{array}$ & $\begin{array}{c}300 \mu \mathrm{mol} / \mathrm{L} \text { for } 2 \\
\text { hours }\end{array}$ & $\begin{array}{l}\text { DHM reduced ROS overproduction, } \\
\text { decreased MDA level and increased SOD } \\
\text { activity and showed antioxidant activity in } \\
\text { HUVECs by activating the } \\
\text { PI3K/Akt/FoxO3a signaling pathway }\end{array}$ & $\begin{array}{l}\text { Xiaoying } \\
\text { et al. (2019) }\end{array}$ \\
\hline DHM 99\% & $\begin{array}{l}\text { Human } \\
\text { umbilical vein } \\
\text { endothelial cells } \\
\text { (HUVECs) }\end{array}$ & $\begin{array}{l}\mathrm{H}_{2} \mathrm{O}_{2} \text {-induced } \\
\text { oxidative stress }\end{array}$ & $\begin{array}{c}37.5-300 \mu \mathrm{M} \text { for } \\
2 \mathrm{~h}\end{array}$ & $\begin{array}{l}\text { DHM inhibited intracellular ROS } \\
\text { overproduction in HUVECs cells }\end{array}$ & $\begin{array}{l}\text { Xiaolong } \\
\text { et al. (2015) }\end{array}$ \\
\hline Ampelopsin $\geq 95 \%$ & PK-15 cells & $\begin{array}{l}\mathrm{H}_{2} \mathrm{O}_{2} \text {-induced } \\
\text { oxidative stress in } \\
\text { PK-15 }\end{array}$ & $\begin{array}{c}0,15,30, \text { and } \\
60 \mu \mathrm{g} / \mathrm{mL} \text { for } 1 \mathrm{~h}\end{array}$ & $\begin{array}{l}\text { Significantly decreased MDA production in } \\
\qquad \mathrm{H}_{2} \mathrm{O}_{2} \text {-induced } \mathrm{PK}-15 \text { cells }\end{array}$ & $\begin{array}{l}\text { Tan et al. } \\
\text { (2010) }\end{array}$ \\
\hline DHM 98\% & Colo-205 cells & $\begin{array}{l}\text { Reactive oxygen } \\
\text { species and MDA }\end{array}$ & $\begin{array}{l}8,16, \text { and } 32 \mu \mathrm{M} \\
\quad \text { for } 2 \mathrm{~h}\end{array}$ & $\begin{array}{l}\text { Inhibited reactive oxygen species and } \\
\text { malondialdehyde levels }\end{array}$ & $\begin{array}{l}\text { Jun et al. } \\
\text { (2019) }\end{array}$ \\
\hline Ampelopsin 98\% & In vitro assay & DPPH method & $\begin{array}{l}0.1 \text { to } 0.4 \mu \mathrm{g} / \mathrm{mL} \\
\quad \text { for } 60 \mathrm{~min}\end{array}$ & $\begin{array}{c}\text { DHM inhibited DPPH radicals with } \mathrm{IC}_{50} \\
\text { value of } 0.235 \mu \mathrm{g} / \mathrm{mL}\end{array}$ & $\begin{array}{l}\text { Wenzhen } \\
\text { et al. (2014) }\end{array}$ \\
\hline DHM 98\% & In vitro assays & $\begin{array}{l}\text { DPPH, ABTS, } \mathrm{O}_{2} \\
\text { radical, and } \mathrm{Fe}^{2+} \\
\text { chelating method }\end{array}$ & $\begin{array}{l}2 \text { to } 20 \mu \mathrm{g} / \mathrm{mL} \text { for } \\
30 \mathrm{~min}\end{array}$ & $\begin{array}{l}\text { Eliminated } \mathrm{ABTS}, \mathrm{DPPH} \text { free radicals, } \\
\text { reduced } \mathrm{Cu}^{2+} \text {, and chelated } \mathrm{Fe}^{2+}\end{array}$ & $\begin{array}{l}\text { Xican et al. } \\
\quad(2016)\end{array}$ \\
\hline $\mathrm{DHM} \geq 98 \%$ & C57BL/6J mice & $\begin{array}{l}\text { Streptozotocin- } \\
\text { induced oxidative } \\
\text { stress model }\end{array}$ & $\begin{array}{c}\text { DHM at } \\
100 \mathrm{mg} / \mathrm{kg} / \text { day for } \\
14 \text { weeks }\end{array}$ & $\begin{array}{l}\text { DHM decreased MDA and increased the } \\
\text { SOD and GSH-Px }\end{array}$ & $\begin{array}{l}\text { Bin et al. } \\
(2017 \mathrm{a})\end{array}$ \\
\hline $\begin{array}{l}\text { DHM (purity not } \\
\text { provided) }\end{array}$ & $\begin{array}{l}\text { Male C57BL/6 } \\
\text { mice }\end{array}$ & $\begin{array}{l}\text { Transverse aortic } \\
\text { constriction induced } \\
\text { oxidative stress in } \\
\text { mice }\end{array}$ & $\begin{array}{c}\text { DHM } \\
(250 \mathrm{mg} / \mathrm{kg} / \text { day }) \\
\text { for } 2 \text { weeks }\end{array}$ & $\begin{array}{l}\text { DHM administration reduced reactive } \\
\text { oxygen species and malondialdehyde level, } \\
\text { and increased total antioxidant capacity and } \\
\text { SOD activity in mice }\end{array}$ & $\begin{array}{l}\text { Yun et al. } \\
\text { (2018) }\end{array}$ \\
\hline DHM > 98.0\% & Chickens & $\begin{array}{l}\text { LPS-induced } \\
\text { oxidative stress in } \\
\text { chickens }\end{array}$ & $\begin{array}{l}0.025 \%, 0.05 \% \text {, } \\
\text { and } 0.1 \% \text { for } 14 \\
\text { days }\end{array}$ & $\begin{array}{l}\text { DHM increased SOD and GSH-Px activity } \\
\text { and GSH in chicken plasma and ileum }\end{array}$ & $\begin{array}{l}\text { Yicong } \\
\text { et al. }(2020)\end{array}$ \\
\hline $\begin{array}{l}\text { DHM (purity not } \\
\text { provided) }\end{array}$ & ICR mice & $\begin{array}{c}\text { Sleep deprivation } \\
\text { induced oxidative } \\
\text { stress }\end{array}$ & $\begin{array}{c}100,50, \text { and } \\
25 \mathrm{mg} / \mathrm{kg} / \text { day for } \\
14 \text { days }\end{array}$ & $\begin{array}{l}\text { DHM increased SOD activity and reduced } \\
\text { MDA level }\end{array}$ & $\begin{array}{l}\text { Hongxiang } \\
\text { et al. (2019) }\end{array}$ \\
\hline $\begin{array}{l}\text { DHM (purity not } \\
\text { provided) }\end{array}$ & Rat & $\begin{array}{l}\text { DPPH radical } \\
\text { scavenging activity } \\
\text { of rat serum }\end{array}$ & $100 \mathrm{mg} / \mathrm{kg} / \mathrm{BW}$ & $\begin{array}{l}\text { DHM increased the antioxidative capacity } \\
\text { of rat serum against DPPH radicals }\end{array}$ & $\begin{array}{l}\text { Xiao et al. } \\
\quad(2014)\end{array}$ \\
\hline Ampelopsin 95\% & Piglets & $\begin{array}{c}\text { LPS-induced } \\
\text { oxidative stress in } \\
\text { piglets }\end{array}$ & $\begin{array}{l}2.5,5, \text { and } \\
10 \mu \mathrm{g} / \mathrm{mL} \text { for } \\
30 \mathrm{~min}\end{array}$ & $\begin{array}{l}\text { Decreased the MDA and protein carbonyl } \\
\text { levels in LPS-treated piglets }\end{array}$ & $\begin{array}{l}\text { Xiang et al. } \\
\quad(2014)\end{array}$ \\
\hline
\end{tabular}

$\mathrm{H}_{2} \mathrm{O}_{2}$, and $\mathrm{O}_{2}$ radicals were 3.24-22.6, 3.1-5.32, 7.95, and $7.79 \mu \mathrm{g} / \mathrm{mL}$, respectively (Table 2) $[5,17,59,60]$.

DHM has been shown to protect oxidative stress in various cell culture models with a concentration below $1000 \mu \mathrm{M}$, as shown in Table 2. Cell lines such as human hepatoma cells (HepG2), human umbilical vein endothelial cells (HUVECs), human colon cancer (Colo-205) cells, porcine kidney epithelial cells (PK-15), PC12 cells, murine macrophage 
(RAW264.7) cells, glomerular mesangial cells (MCs), and HEI-OC1 auditory cells have been successfully used to determine the protective effects of DHM in oxidative stress, and oxidative stress is generally created in cell lines by using $\mathrm{H}_{2} \mathrm{O}_{2}$ free radicals, LPS, methylglyoxal, and sodium nitroprusside $[4,41,47,55,61-67]$.

Oxidative stress-induced mice, rat, chicken, and piglet models have also been used by many researchers to investigate the protective role of DHM in oxidative stress. The dose used in animal studies was 25 to $250 \mathrm{mg} / \mathrm{kg} \mathrm{BW}$, and the duration was between 2 and 3 months. In animal studies, superoxide dismutase (SOD), glutathione peroxidase (GSH$\mathrm{Px})$, glutathione (GSH), and malondialdehyde (MDA) are commonly measured oxidative stress parameters to estimate the antioxidant capacity of DHM [13, 68-70]. The major antioxidant effects of DHM through the Nrf2/HO-1 pathway, the Nrf2/Keap1 pathway, and the ERK and Akt pathways $[5,62,66,71]$, with an increase of DHM, significantly decreased the ROS levels in human umbilical vein endothelial cells (HUVECs) [71]. DHM exhibited an antioxidative power by activating superoxide dismutase (SOD) and the Nrf2/HO-1 signaling pathway or the Nrf2/Keap1 pathway $[5,64]$. Recently, Dong et al. found that DHM exhibited antioxidative effects through the inhibition of intracellular ROS production and expression levels of ROS producing the enzymes NADPH oxidase 2 (NOX2) and NOX4, the suppression of MDA levels, the enhancement of SOD, and the activation of the Nrf2/HO-1 signaling pathway [66]. In another study, Zhang et al. determined the protective effects of DHM on HUVECs against sodium nitroprusside- (SNP) induced oxidative damage and reported that DHM reduced ROS production and MDA levels, and increased SOD activity by activating the PI3K/Akt/FoxO3a signaling pathways in HUVECs [65]. DHM was also reported to inhibit the oxidative stress in HEI-OC1 auditory cells through the suppression of ROS accumulation [67]. DHM inhibited the activity of phase I enzymes, including cytochrome P450 (CYP), and phase II enzymes, including sulfotransferases (SULTs) and N/O-acetyltransferases (NAT1 and NAT2) [72, 73]. Oxidative stress has been involved in several neurodegenerative diseases such as Parkinson's disease, Alzheimer's disease (AD), and Huntington's disease [62]. Several researchers investigated the neuroprotective effect of DHM in oxidative stress-induced PC12 neuronal-like cells. They also investigated the neuroprotective role of DHM in neuronal-like PC12 cells against $\mathrm{H}_{2} \mathrm{O}_{2}$-induced oxidative stress and reported that DHM treatment at 1,5 , and $15 \mathrm{mg} / \mathrm{mL}$ for $1 \mathrm{~h}$ inhibited the formation of ROS and increased the cellular antioxidant defense through activation of the ERK and Akt signaling pathways in PC12 cells [62]. Jiang et al. found that DHM reduced the oxidative stress in PC12 cells by inhibiting the intracellular ROS production and by modulating the AMPK/GLUT4 signaling pathways [63].

The oxidative stress protection capacity of DHM was also evaluated in several animal models. DHM showed the highest radical scavenging activity $(42.26 \%)$ of serum at $4 \mathrm{~h}$ after DHM administration in rats [57]. Li et al. induced oxidative stress in the brains of ICR mice by sleep deprivation and found that DHM administration significantly reduced oxida- tive stress by increasing SOD activity and reducing the MDA level in the hippocampus of sleep-deprived mice [69]. Similarly, for streptozotocin-induced or transverse aortic constriction surgery-induced oxidative stress in mice as well as high-fat diet-induced oxidative stress in rats, DHM decreased MDA and increased SOD, GSH, and GSH-Px $[13,74,75]$. When induced by LPS to cause oxidative stress, DHM increased total antioxidant capacity and reduced the MDA levels in piglets, and increased SOD and GSH-Px activity and GSH in chicken plasma and ileum $[55,70]$. The scientific evidence from in vitro, cell culture, and animal studies clearly indicate that DHM could prevent the free radicals, oxidative stress, and related markers. However, scientific data related to the antioxidant capacity of DHM in humans is scanty. Therefore, more clinical investigations are needed to improve the therapeutic applications of DHM as a natural antioxidant.

\section{Anti-Inflammatory Capacity Is Fundamental and Is the Immediate Reason for Its Anticancer Efficacy}

Inflammation is a complex and normal response of the immune system to external stimuli such as pathogens, toxins, chemical agents, infection, and tissue injury. When inflammatory cells (e.g., macrophages) are activated by stimuli (e.g., LPS and IFN- $\gamma$ ), inflammatory mediators such as IL$1 \beta$, IL-6, TNF- $\alpha$, NO, and PGE2 are excessively produced through the activation of common inflammatory signaling pathways such as the NF- $\kappa$ B, MAPK, and JAK-STAT pathways [76]. The overproduction of inflammatory mediators (IL-1 $\beta$, IL-6, TNF- $\alpha$, NO, and PGE2) has been associated with several diseases such as diabetes, cancer, asthma, metabolic syndrome, arthritis, cardiovascular diseases, and inflammatory bowel diseases [77]. Recently, there has been growing interest in nutraceuticals and functional foods derived from plant sources. Flavonoids are polyphenolic compounds largely present in vegetables, fruits, legumes, and tea. Flavonoids such as quercetin, cyanidin, luteolin, anthocyanidin, catechin, and epicatechin have shown to contain anti-inflammatory properties [78]. DHM has been extensively studied by many researchers for its antiinflammatory activities using various cell cultures, animal models, and human studies. Several researchers used different inflammatory models (neuroinflammation, arthritis inflammation, and lung inflammation) to investigate the anti-inflammatory potential of DHM. Table 3 shows the various models used and the molecular mechanisms of the antiinflammatory property of DHM.

The most widely used model for the investigation of the anti-inflammatory activity of plant-derived compounds is the macrophage that is stimulated by LPS. Macrophages play an important role in inflammation. The murine RAW264.7 macrophage cell line is the most commonly used cell culture model for the determination of the anti-inflammatory activity of food-derived compounds. Macrophages stimulated by the Toll-like receptor ligand LPS produce various inflammatory markers such as TNF- $\alpha$, IL-6, IL- $1 \beta$, NO, transcription 
TABLE 3: Anti-inflammatory activities and mechanisms of the action of DHM.

\begin{tabular}{|c|c|c|c|c|}
\hline Treatment methods & Mode of administration & $\begin{array}{l}\text { Dose and duration } \\
\text { time }\end{array}$ & $\begin{array}{c}\text { Mechanism of action/activities/effects } \\
\text { showed }\end{array}$ & Reference \\
\hline LPS-induced inflammation & & $\begin{array}{c}50,100, \text { and } \\
150 \mu \mathrm{g} / \mathrm{mL} \text { for } 2 \mathrm{~h}\end{array}$ & $\begin{array}{c}\text { Showed anti-inflammatory activity by } \\
\text { inhibiting interconnected } \\
\text { ROS/Akt/IKK/NF- } \kappa \text { B signaling pathways. } \\
\text { Significantly inhibited the release of nitric } \\
\text { oxide (NO) and proinflammatory cytokines } \\
\text { such as IL-1 } \beta \text {, IL- } 6 \text {, and TNF- } \alpha \text { in a dose- } \\
\text { dependent manner }\end{array}$ & $\begin{array}{l}\text { Shimei } \\
\text { et al. } \\
(2012)\end{array}$ \\
\hline $\begin{array}{l}\text { LPS-induced inflammation in } \\
\text { RAW264.7 cells }\end{array}$ & & $\begin{array}{l}0.4,0.8,1.5,3,6.2 \\
12.5,25,50, \text { and } \\
100 \mu \mathrm{M} \text { for } 24 \mathrm{~h}\end{array}$ & $\begin{array}{l}\text { Showed anti-inflammatory effects through } \\
\text { the inhibition of the release of nitric oxide } \\
\text { (NO) in RAW macrophages }\end{array}$ & $\begin{array}{l}\text { Yuemei } \\
\text { et al. } \\
(2019)\end{array}$ \\
\hline $\begin{array}{l}\text { A549 cells were stimulated } \\
\text { with TLR3 agonist poly(I:C) }\end{array}$ & & $\begin{array}{l}25,50 \text {, and } 100 \mu \mathrm{M} \\
\text { for } 3 \text { days }\end{array}$ & $\begin{array}{l}\text { Attenuated inflammation through TLR3 } \\
\text { pathway }\end{array}$ & $\begin{array}{l}\text { Yuanxin } \\
\text { et al. } \\
(2020)\end{array}$ \\
\hline $\begin{array}{l}\text { TNF- } \alpha \text {-induced } \\
\text { inflammation in HUVECs }\end{array}$ & & $\begin{array}{l}5,10,25,50,75 \text {, and } \\
100 ? \mathrm{M} \text { for } 24 \mathrm{~h}\end{array}$ & $\begin{array}{l}\text { Attenuated endothelial dysfunction induced } \\
\text { by TNF- } \alpha \text { in a miR-21-dependent manner }\end{array}$ & $\begin{array}{l}\text { Dafeng } \\
\text { et al. } \\
(2018)\end{array}$ \\
\hline $\begin{array}{l}\text { TNF- } \alpha \text {-induced } \\
\text { inflammation }\end{array}$ & & $\begin{array}{l}50-200 \mu \mathrm{M} \text { for } 24 \\
\text { hours }\end{array}$ & $\begin{array}{c}\text { Showed anti-inflammatory activity via } \\
\text { suppression of TNF- } \alpha \text {-induced NF- } \kappa \mathrm{B} \\
\text { activation }\end{array}$ & $\begin{array}{l}\text { Nina et al. } \\
\text { (2016) }\end{array}$ \\
\hline $\begin{array}{l}\text { LPS-induced cardiomyocyte } \\
\text { inflammation }\end{array}$ & & $\begin{array}{l}25,50 \text {, and } 100 \mu \mathrm{M} \\
\quad \text { for } 12 \mathrm{~h}\end{array}$ & $\begin{array}{c}\text { Exhibited anti-inflammatory activity in } \\
\text { cardiomyocytes by reducing TNF- } \alpha \text { and IL- } \\
6 \text { levels via inhibition of the TLR } 4 \text { /NF- } \kappa \text { B } \\
\text { signaling pathways }\end{array}$ & $\begin{array}{l}\text { Meng- } \\
\text { qiao et al. } \\
\text { (2017) }\end{array}$ \\
\hline $\begin{array}{l}\text { LPS-induced inflammation in } \\
\text { BV-2 cells }\end{array}$ & & $\begin{array}{l}10,25 \text {, and } 50 \mu \mathrm{M} \\
\text { for } 24 \mathrm{~h}\end{array}$ & $\begin{array}{l}\text { DHM significantly reduced LPS-induced } \\
\text { NO, IL- } 6 \text {, and TNF- } \alpha \text { production and levels } \\
\text { of iNOS and COX- } 2 \text { in BV- } 2 \text { cells }\end{array}$ & $\begin{array}{l}\text { Yafei et al. } \\
\text { (2017) }\end{array}$ \\
\hline $\begin{array}{l}\text { LPS-induced inflammation in } \\
\text { BV-2 cells }\end{array}$ & & $\begin{array}{c}20,40,80, \text { or } \\
100 \mathrm{mg} / \mathrm{L} \text { for } 48 \mathrm{~h}\end{array}$ & $\begin{array}{l}\text { DHM exhibited the anti-inflammatory effect } \\
\text { on LPS-induced BV-2 microglial cells } \\
\text { through the TRL } 4 / \mathrm{NF}-\kappa \mathrm{B} \text { signaling pathway } \\
\text { and suppressed the levels of IL- } 6 \text {, IL- } 1 \beta \text {, and } \\
\text { TNF- } \alpha \text {, and inhibited the protein expression } \\
\text { of iNOS and COX- } 2\end{array}$ & $\begin{array}{l}\text { Nianshui } \\
\text { et al. } \\
(2019)\end{array}$ \\
\hline $\begin{array}{l}\text { TPA-induced acute } \\
\text { inflammation/LPS-induced } \\
\text { RAW } 264.7 \text { macrophage cells }\end{array}$ & Topical application & $\begin{array}{c}2.3 \text { and } 4.6 \mathrm{mg} \text { per } \\
\text { ear for } 5 \mathrm{~h} / 37.5,75 \text {, } \\
150 \text {, and } 300 \mu \mathrm{M} \text { for } \\
2 \mathrm{~h}\end{array}$ & $\begin{array}{l}\text { Showed anti-inflammatory activity through } \\
\text { suppressing the activation of NF- } \kappa \text { B and the } \\
\text { phosphorylation of p } 38 \text { and JNK. Inhibited } \\
\text { the levels of proinflammatory cytokines } \\
\text { such as TNF- } \alpha \text {, IL- } 1 \beta \text {, and IL- } 6 \text { as well as } \\
\text { increased the level of the anti-inflammatory } \\
\text { cytokine IL-10 in LPS-treated mice. Reduced } \\
\text { the protein expression of iNOS, TNF- } \alpha \text {, and } \\
\text { COX- } 2 \text { in RAW cells }\end{array}$ & $\begin{array}{l}\text { Hou et al. } \\
\quad(2015)\end{array}$ \\
\hline LPS-induced inflammation & $\begin{array}{l}\text { Amp was dissolved in } \\
\text { dimethylsulfoxide } \\
\text { (DMSO), and dilutions } \\
\text { were made in DMEM }\end{array}$ & $0.5 \mu \mathrm{g} / \mathrm{mL}$ for $24 \mathrm{~h}$ & $\begin{array}{c}\text { Reduced the phosphorylation levels of } \\
\text { JAK2-STAT3 and STAT3 nuclear } \\
\text { translocation and suppressed LPS-induced } \\
\text { activation of the I } \kappa \text { B/NF- } \kappa \text { B inflammation } \\
\text { pathway. Decreased the production of NO } \\
\text { and PGE2 and suppressed the expression of } \\
\text { iNOS and COX-2 and reduced } \\
\text { proinflammatory cytokines such as IL- } 1 \beta \text {, } \\
\text { IL- } 6 \text {, and TNF- } \alpha\end{array}$ & $\begin{array}{l}\text { Leihua } \\
\text { et al. } \\
(2017)\end{array}$ \\
\hline $\begin{array}{l}\text { Ovalbumin- (OVA-) induced } \\
\text { inflammation in C57BL/6 } \\
\text { mouse }\end{array}$ & $\begin{array}{l}\text { Administered } \\
\text { intraperitoneally }\end{array}$ & $\begin{array}{c}10 \mathrm{mg} / \mathrm{kg} \mathrm{BW} \text { for } 14 \\
\text { days }\end{array}$ & $\begin{array}{c}\text { DHM exhibited anti-inflammatory activity } \\
\text { by reducing the levels of IL-4, IL-5, and IL- } \\
13 \text { in the bronchoalveolar lavage fluid in an } \\
\text { OVA-induced asthma model }\end{array}$ & $\begin{array}{l}\text { Bin et al. } \\
(2017)\end{array}$ \\
\hline $\begin{array}{l}\text { Doxorubicin- (DOX-) } \\
\text { induced cardiotoxicity rat }\end{array}$ & $\begin{array}{l}\text { Administered } \\
\text { intragastrically }\end{array}$ & & $\begin{array}{l}\text { DHM protected against DOX-induced } \\
\text { cardiotoxicity by inhibiting NLRP3 }\end{array}$ & \\
\hline
\end{tabular}


TABle 3: Continued.

\begin{tabular}{|c|c|c|c|c|}
\hline Treatment methods & Mode of administration & $\begin{array}{l}\text { Dose and duration } \\
\text { time }\end{array}$ & $\begin{array}{c}\text { Mechanism of action/activities/effects } \\
\text { showed }\end{array}$ & Reference \\
\hline $\begin{array}{l}\text { model and DOX-induced } \\
\text { H9C2 cells }\end{array}$ & & $\begin{array}{c}100 \mathrm{mg} / \mathrm{kg} / \text { day or } \\
200 \mathrm{mg} / \mathrm{kg} / \text { day for } 6 \\
\text { weeks }\end{array}$ & $\begin{array}{l}\text { inflammasome activation via stimulation of } \\
\text { the SIRT1 pathway and suppressed IL- } 1 \beta \\
\text { and IL-18 release, and upregulated SIRT1 } \\
\text { protein levels in vivo and in vitro }\end{array}$ & $\begin{array}{l}\text { Zhenzhu } \\
\text { et al. } \\
(2020)\end{array}$ \\
\hline $\begin{array}{l}\text { Cecal ligation and puncture- } \\
\text { (CLP-) induced lung injury } \\
\text { model }\end{array}$ & Orally administered & $\begin{array}{l}50,100, \\
150 \mathrm{mg} / \mathrm{kg} / \text { day for } 3 \\
\text { days }\end{array}$ & $\begin{array}{l}\text { DHM treatment significantly inhibited the } \\
\text { CLP-induced NLRP3 inflammasome } \\
\text { pathway, IL- } 1 \beta \text {, and IL-18 }\end{array}$ & $\begin{array}{l}\text { Yu-Chang } \\
\text { et al. } \\
\text { (2019) }\end{array}$ \\
\hline LPS-mediated inflammation & $\begin{array}{l}\text { Diet supplemented with } \\
\text { ampelopsin }\end{array}$ & $\begin{array}{l}100 \text { and } 400 \mathrm{mg} / \mathrm{kg} \\
\text { BW for } 28 \text { days }\end{array}$ & $\begin{array}{c}\text { Showed the anti-inflammatory activity } \\
\text { through the reduction of activation of AKT } \\
\text { and STAT3 phosphorylation and } \\
\text { suppressed the DNA-binding activity of NF- } \\
\kappa \text { B. Decreased the proinflammatory } \\
\text { mediators such as TNF- } \alpha \text {, IL- } 1 \beta \text {, IL- } 6 \text {, and } \\
\text { COX- } 2\end{array}$ & $\begin{array}{l}\text { Xiang } \\
\text { et al. } \\
(2017)\end{array}$ \\
\hline Double-blind clinical trial & Orally administered & $\begin{array}{c}\text { Four } 150 \mathrm{mg} \\
\text { capsules daily for } 12 \\
\text { weeks }\end{array}$ & $\begin{array}{l}\text { Exhibited anti-inflammatory activity by } \\
\text { decreasing the serum levels of TNF- } \alpha \text {, } \\
\text { cytokeratin-18 fragment, and fibroblast } \\
\text { growth factor } 21\end{array}$ & $\begin{array}{l}\text { Shihui } \\
\text { et al. } \\
(2015)\end{array}$ \\
\hline $\begin{array}{l}\text { APP/PS1 double transgenic } \\
\text { mice }\end{array}$ & Injected intraperitoneally & $\begin{array}{l}1 \mathrm{mg} / \mathrm{kg} \mathrm{BW} \text { for } 2 \\
\text { and } 4 \text { weeks }\end{array}$ & $\begin{array}{l}\text { DHM reduced activation of NLRP3 } \\
\text { inflammasomes and reduced expression of } \\
\text { NLRP3 inflammasome components and } \\
\text { decreased IL-1 } \beta \text { in transgenic mice }\end{array}$ & $\begin{array}{c}\text { Jie et al. } \\
(2018)\end{array}$ \\
\hline $\begin{array}{l}\text { Collagen-induced } \\
\text { inflammation }\end{array}$ & Intraperitoneally & $\begin{array}{l}5,25 \text {, and } 50 \mathrm{mg} / \mathrm{kg} \\
\text { BW every other day } \\
\text { for } 5 \text { weeks }\end{array}$ & $\begin{array}{c}\text { Alleviated inflammation in rats by } \\
\text { attenuating IL- } 1 \beta \text { production via } \\
\text { suppression of NF- } \kappa \text { B signaling }\end{array}$ & $\begin{array}{l}\text { Jing et al. } \\
\text { (2019) }\end{array}$ \\
\hline $\begin{array}{l}\text { Lead- }(\mathrm{Pb}-) \text { stimulated } \\
\text { inflammation }\end{array}$ & Oral gavage administration & $\begin{array}{l}125 \text { and } \\
250 \mathrm{mg} / \mathrm{kg} / \mathrm{BW} \text { for } \\
3 \text { months }\end{array}$ & $\begin{array}{l}\text { Inhibited } \mathrm{Pb} \text {-induced inflammation by } \\
\text { regulating the AMPK, A } \beta \text {, TLR4, MyD88, } \\
\text { p38, and GSK-3 } \beta \text { pathways }\end{array}$ & $\begin{array}{l}\text { Chan-Min } \\
\text { et al. } \\
\text { (2018) }\end{array}$ \\
\hline $\begin{array}{l}\text { Caerulin-induced } \\
\text { inflammation in mice and } \\
\text { BMDMs }\end{array}$ & Intraperitoneally & $\begin{array}{l}\text { Single dose of } \\
25 / 100 \mathrm{mg} / \mathrm{kg}\end{array}$ & $\begin{array}{l}\text { Inhibited production of proinflammatory } \\
\text { cytokines IL- } 1 \beta \text {, TNF- } \alpha \text {, and IL-17 in mice } \\
\text { and BMDMs }\end{array}$ & $\begin{array}{l}\text { Rongrong } \\
\text { et al. } \\
(2018)\end{array}$ \\
\hline $\begin{array}{l}\text { LPS-induced inflammation in } \\
\text { chickens }\end{array}$ & Feeding in the diet & $\begin{array}{l}0.025,0.05 \text {, and } \\
0.1 \mathrm{mg} / \mathrm{kg} \text { for } 14 \\
\text { days }\end{array}$ & $\begin{array}{l}\text { DHM reduced inflammation by inhibiting } \\
\text { NLRP3 inflammasome and TLR4/NF- } \kappa \mathrm{B} \\
\text { signaling pathway in ileum in chickens }\end{array}$ & $\begin{array}{l}\text { Yicong } \\
\text { et al. } \\
(2020)\end{array}$ \\
\hline $\begin{array}{l}\text { Mice transplanted with Colo- } \\
205 \text { cells }\end{array}$ & Intragastric administration & $\begin{array}{c}25,50, \text { and } \\
100 \mathrm{mg} / \mathrm{kg} \text { for } 21 \\
\text { days }\end{array}$ & $\begin{array}{l}\text { Decreased the levels of IL- } 1 \beta \text {, IL- } 6 \text {, IL- } 8 \text {, and } \\
\text { TNF- } \alpha \text { as well as reduced the expression of } \\
\text { COX- } 2 \text { and iNOS }\end{array}$ & $\begin{array}{l}\text { Jun et al. } \\
2019\end{array}$ \\
\hline $\begin{array}{l}\text { LPS-induced inflammation in } \\
\text { lung tissue }\end{array}$ & Oral gavage administration & $\begin{array}{l}500 \mathrm{mg} / \mathrm{kg} \mathrm{BW} \text { for } 4 \\
\text { days }\end{array}$ & $\begin{array}{l}\text { Exhibited anti-inflammatory effects by } \\
\text { inhibiting the MAPK signaling pathway as } \\
\text { well as TNF- } \alpha \text {, IL-1?, and IL- } 6 \text { levels }\end{array}$ & $\begin{array}{l}\text { Bo et al. } \\
(2018)\end{array}$ \\
\hline $\begin{array}{l}\text { A rat model of inflammation } \\
\text { induced by collagen }\end{array}$ & Intraperitoneally & $\begin{array}{l}5,25 \text {, and } 50 \mathrm{mg} / \mathrm{kg} \\
\quad \text { for } 5 \text { weeks }\end{array}$ & $\begin{array}{l}\text { Exhibited anti-inflammatory effects by } \\
\text { inhibiting NF- } \kappa \text { B signaling pathway }\end{array}$ & $\begin{array}{l}\text { Jing et al. } \\
\text { (2020) }\end{array}$ \\
\hline $\begin{array}{l}\text { Carrageenan-induced paw } \\
\text { edema in rat and LPS- } \\
\text { induced inflammation in } \\
\text { RAW264.7 model }\end{array}$ & Intraperitoneal injection & $\begin{array}{l}50,100, \text { and } \\
250 \mathrm{mg} / \mathrm{kg} \text { for } 7 \\
\text { days }\end{array}$ & $\begin{array}{l}\text { DHM significantly reduced rat paw edema } \\
\text { induced by carrageenan and noticeably } \\
\text { inhibited NO secretion, iNOS, and COX-2 } \\
\text { protein expression and decreased p65 } \\
\text { phosphorylation via suppression of IKK- } \beta \\
\text { activity and IKK- } \alpha / \beta \text { phosphorylation }\end{array}$ & $\begin{array}{l}\text { Rui et al. } \\
\text { (2016) }\end{array}$ \\
\hline $\begin{array}{l}\text { Complete Freund's } \\
\text { Adjuvant- (CFA-) induced } \\
\text { inflammation in rheumatoid } \\
\text { arthritis model }\end{array}$ & Gavage administration & $\begin{array}{l}20 \text { and } 50 \mathrm{mg} / \mathrm{kg} \\
\text { per day for } 25 \text { days }\end{array}$ & $\begin{array}{c}\text { DHM inhibited the expressions of } \\
\text { proinflammatory cytokines IL- } 1 \beta \text {, IL- } 6 \text {, } \\
\text { TNF- } \alpha \text {, and COX- } 2 \text { via activating the Nrf } 2 \\
\text { pathway }\end{array}$ & $\begin{array}{l}\text { Jianguo } \\
\text { et al. } \\
(2018)\end{array}$ \\
\hline \multirow[t]{2}{*}{$\begin{array}{l}\text { Streptozotocin-induced } \\
\text { diabetic inflammation }\end{array}$} & Intragastrically given & $\begin{array}{l}100 \mathrm{mg} / \mathrm{kg} / \text { day for } \\
14 \text { weeks }\end{array}$ & $\begin{array}{l}\text { DHM reduced the levels of proinflammatory } \\
\text { factors such as IL- } 6 \text { and TNF- } \alpha\end{array}$ & $\begin{array}{c}\text { Bin et al. } \\
(2017 \mathrm{a})\end{array}$ \\
\hline & Incorporated in the diet & & & \\
\hline
\end{tabular}


TABLe 3: Continued.

\begin{tabular}{|c|c|c|c|c|}
\hline Treatment methods & Mode of administration & $\begin{array}{l}\text { Dose and duration } \\
\text { time }\end{array}$ & $\begin{array}{c}\text { Mechanism of action/activities/effects } \\
\text { showed }\end{array}$ & Reference \\
\hline $\begin{array}{l}\text { Alcohol-induced } \\
\text { inflammation in C57BL/6 } \\
\text { mice }\end{array}$ & & $\begin{array}{l}75 \text { and } 150 \mathrm{mg} / \mathrm{kg} \\
\text { BW for } 6 \text { weeks }\end{array}$ & $\begin{array}{l}\text { DHM considerably alleviated the hepatic IL- } \\
\qquad 1 \beta \text { and IL- } 6 \text { levels }\end{array}$ & $\begin{array}{l}\text { Ping et al. } \\
\text { (2017) }\end{array}$ \\
\hline
\end{tabular}

factor $\mathrm{NF}-\kappa \mathrm{B}$, and prostaglandin-E2 that regulate the inflammatory responses. Numerous studies reported that DHM showed anti-inflammatory activity through different molecular mechanisms such as suppression of proinflammatory cytokines (IL- $1 \beta$, IL-6, IL- 8 , and TNF- $\alpha$ ), activation of the production of an anti-inflammatory cytokine (IL-10), inhibition of MAPKs, suppression of the production of prostaglandins and nitric oxide, and inhibition of the transcription factor NF- $\kappa \mathrm{B}[3,4,79,80]$.

The inflammatory response of the brain or the spinal cord is known as neuroinflammation, and it has an important role in the development of depression by producing cytokines, chemokines, and ROS [26]. Microglial cells are macrophages in the central nervous system and are commonly used as a model to investigate the protective effects of DHM in neuroinflammation. Several researchers evaluated the anti-inflammatory capacity of DHM in neuroinflammation using microglial cells and mice models. Weng et al. investigated the neuroinflammation protection capacity of DHM using murine BV-2 microglial cells activated by LPS and reported that DHM inhibited neuroinflammation by suppressing the $\mathrm{I} \kappa \mathrm{B} / \mathrm{NF}-\kappa \mathrm{B}$ inflammation pathway as well as decreasing STAT3 nuclear translocation and the phosphorylation levels of JAK2-STAT3. Additionally, the authors demonstrated that DHM treatment significantly inhibited the production of inflammatory mediators IL- $1 \beta$, IL-6, TNF- $\alpha$, nitric oxide (NO), prostaglandin E2 (PGE2), and the enzymes inducible nitric oxide synthase (iNOS) and cyclooxygenase-2 (COX-2) in LPS-induced microglial cells. DHM treatment at 10 and $20 \mathrm{mg} / \mathrm{kg} /$ day for 3 days showed an antidepressant-like activity by significantly inhibiting TNF- $\alpha$ and IL- 6 gene expressions and protein levels in a mice model of LPS-induced neuroinflammation [81]. DHM at $1 \mathrm{mg} / \mathrm{kg}$ BW for 4 weeks significantly inhibited the neuroinflammation of APP/PS1 double transgenic mice by decreasing IL- $1 \beta$ via reduction of the activation of NLRP3 inflammasomes [82]. In a lead- ( $\mathrm{Pb}-)$ induced inflammation model in mice, $\mathrm{Pb}$ combined with $\mathrm{DHM}$ administration at a dose of 125 and $250 \mathrm{mg} / \mathrm{kg} / \mathrm{BW}$ significantly inhibited TNF- $\alpha$ and IL- $1 \beta$ and the nuclear translocation of NF- $\kappa \mathrm{B}$ p65 via regulating the AMPK, $\mathrm{A} \beta$, TLR4, MyD88, $\mathrm{p} 38$, and GSK-3 $\beta$ signaling pathways. DHM exhibited an antiinflammatory effect on LPS-induced BV-2 microglial cells by suppressing the proinflammatory markers IL-6, IL- $1 \beta$, TNF- $\alpha$, iNOS, and COX- 2 through reducing the activation of the TRL4/NF- $\kappa \mathrm{B}$ signaling pathway. These studies proved that DHM possess neuroinflammation protection activity through the inhibition of inflammatory mediators.

The anti-inflammatory effects of DHM were investigated with the administration of a DHM dosage from 0.025 to $500 \mathrm{mg} / \mathrm{kg} \mathrm{BW}$ within 2 weeks to 14 weeks. Xu et al. studied the anti-inflammatory capacity of DHM in an ovalbumin(OVA-) induced mice C57BL/6 model of asthma and demonstrated that DHM treatment significantly decreased the levels of IL-4, IL-5, and IL-13 in the bronchoalveolar lavage fluid compared to the control group [83]. DHM treatment significantly suppressed IL- $1 \beta$ and IL-18 production by inhibiting the NLRP3 inflammasome through the activation of the SIRT1 signaling pathway in a doxorubicin- (DOX-) induced rat model and in DOX-treated H9C2 cells [84]. DHM was found to reduce the inflammation in CIA rats by attenuating IL- $1 \beta$ production through the suppression of the NF- $\kappa \mathrm{B}$ signaling pathway [85]. Chu et al. reported that DHM significantly reduced the inflammation in a rat model of rheumatoid arthritis by inhibiting the levels of inflammatory mediators IL- $1 \beta$, IL- 6 , TNF- $\alpha$, and COX-2 via activating the Nrf2 pathway [86]. Chang et al. investigated the protective role of DHM in ileum inflammation, induced by LPS, in chickens and found that DHM treatment decreased IL$1 \beta$ and IL-18 expression through the inhibition of the TLR4/NF- $\kappa \mathrm{B}$ signaling pathways. DHM significantly decreased the proinflammatory cytokines TNF- $\alpha$, IL- $1 \beta$, and IL- 6 and the COX-2 gene expressions and increased the production of IL-10 in the liver of piglets injected with LPS [21]. Additionally, the authors demonstrated that DHM supplementation in LPS-treated piglets decreased the activation of AKT and STAT3 phosphorylation and reduced the DNA-binding activity of NF- $\kappa \mathrm{B}[21]$.

More importantly, the anti-inflammatory activity of DHM was also determined in humans. Chen et al. conducted a randomized double-blind controlled clinical trial with sixty adult nonalcoholic fatty liver disease patients, and the DHM was administered (150 mg capsules) twice daily for 12 weeks [87]. The authors found that DHM exhibited an antiinflammatory activity in humans by decreasing the serum levels of TNF- $\alpha$, cytokeratin-18 fragment, and fibroblast growth factor 21 .

Although sufficient evidence is available from cell culture and animal experiments, the results from clinical studies are meager. Therefore, it is suggested that more studies are needed in humans to further confirm the anti-inflammatory activity of DHM. More results from human studies would provide strong scientific evidence for using DHM as a therapeutic agent to treat inflammation and its related diseases.

\section{Gut Microbiota Is a Potential Interface for the Regulation of Redox Balance for Cancer Prevention}

The interface of gut microbiota is very important for cancer chemoprevention of DHM, and the interaction between 


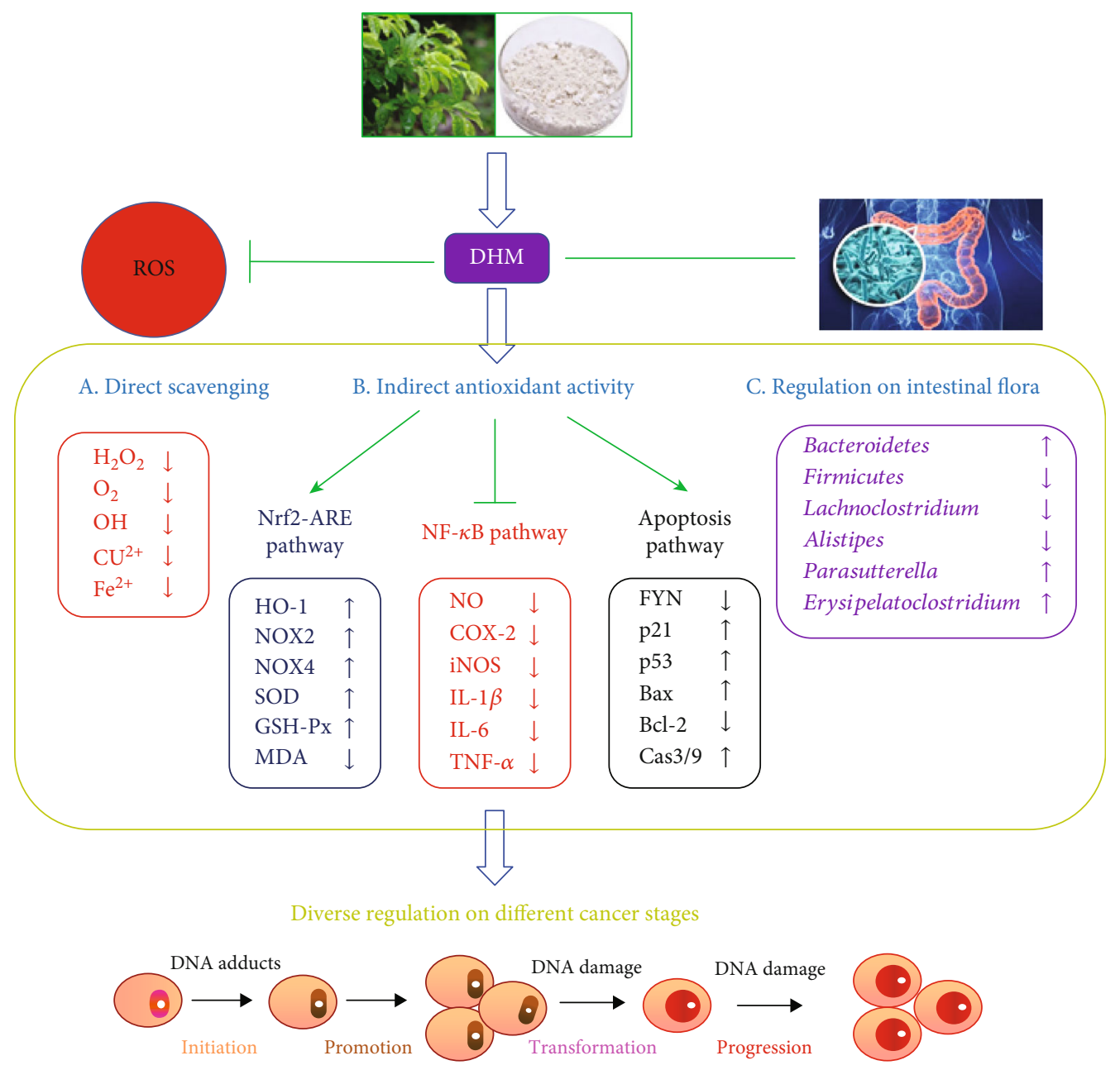

FIgURE 2: Molecular mechanism diagram of the inhibitory effect of DHM on cancer.

DHM and gut microbiota is the key stage for its mechanism study. DHM is a flavonoid with poor oral bioavailability in vivo because of its rare absorption in the gastrointestinal tract (GI). Due to the low bioavailability, the vast majority of DHM persists in the colon where it is exposed to the gut microbiota, which markedly alters the richness and diversity of the gut microbiota and modulates the gut microbiota composition [88]. Previous studies indicated that DHM could be distributed widely in different organs such as the liver, kidney, lung, brain, and heart, whereas most of them were eliminated in feces, which indicated that DHM is predominantly distributed in the intestinal tract, and closely interacts with the gut microbiota [89].

It is reported that DHM treatment could obviously change the relative abundances of gut microbiota at different levels [90]. DHM is able to dramatically increase the abundance of Bacteroidetes but decrease the abundance of Firmicutes, which was related to obesity intervention in humans. In brief, decreasing the ratio of Firmicutes to Bacteroidetes was demonstrated to control body weight via modulatory glucose and lipid metabolism. Besides, DHM supplement can decrease the abundances of Lachnoclostridium, Alistipes, Ruminococcaceae UCG-010, Allobaculum, Ruminiclostridium 9, Rikenellaceae RC9, Ruminococcaceae UCG-005,
Anaerotruncus, Defluvitaleaceae UCG-011, [Eubacterium] ventriosum, Christensenellaceae R-7, and Odoribacter, whereas it can increase the abundances of Parasutterella, Erysipelatoclostridium, and Parabacteroides [91]. Thus, a lot of evidences suggested that DHM supplement could intervene against chronic diseases, such as obesity, diabetes, and cancers, via modulating the gut microbiota composition [92].

Moreover, the interaction between DHM and gut microbiota is reported to be associated with cancer. DHM was reported to promote the CPT-11 effect both in the mouse model of AOM/DSS cancer; tumors were sensitive to $100 \mathrm{mg} / \mathrm{kg}$ DHM chemotherapy under $100 \mathrm{mg} / \mathrm{kg}$ or 200 mg/kg CPT-11 (irinotecan). DHM-driven CPT-11 chemotherapy induced enhanced IgG levels and the reduction of Fusobacterium abundance in the gut [91]. Besides, the intestinal tract is the most import target organ for DHM intervention associated with the chemotherapeutic efficacy and reduced risk of the side effects of cancer treatment via the regulation of immune responses and the shaping of gut microbiota [92].

On the other hand, DHM was reported to be biotransformed into other metabolites by gut microbiota via methylation, reduction, dehydroxylation, glucuronidation, and sulfation pathways which may be closely related to the 
regulation of redox balance [93]. Therefore, gut microbiota is a potential important interface for regulating the redox balance for providing more therapeutic schedules on various other human diseases.

\section{Conclusions and Perspectives}

DHM originated from a natural plant in China and has received increasing attention due to its pharmacological activities. In this review, the physicochemical properties of DHM have been mentioned. Its antioxidant, anti-inflammatory, and anticancer activities and related molecular mechanisms have been further reviewed. The molecular mechanism diagram of the inhibitory effect of DHM on cancer has been summarized as shown in Figure 2. In brief, DHM exerts its anticancer activity via direct scavenging of ROS, regulating intestinal microbiota, and indirectly modulating the cellular signaling pathway, including the activation of the Nrf2-ARE pathway, the inhibition of the NF- $\kappa$ B pathway, and the induction of the apoptosis pathway.

Substantial scientific evidence about the functional properties of DHM is available from cell culture and animal studies. DHM exhibited bioactivities by modulating several molecular pathways. However, the mechanism of pharmacological action, distribution, and metabolism are still not well investigated in vivo in animals, and what is more, the evidence from clinical studies is meager. The novel targets of the signaling transduction of DHM still require more work. Furthermore, more studies are needed in humans in order improve the applications of DHM in food and pharmaceutical industries. The future in vivo researches by multiomics technologies are required to understand the safety, bioavailability, and metabolism mechanism of DHM targeting on oxidative stress, inflammation, and cancer, especially to reveal the reciprocal interaction among DHM, cells/organs, and gut microbiota. This could pave ways for the industry applications of DHM as a functional food/healthy food/therapeutic agent.

\section{Abbreviations}

\begin{tabular}{|c|c|}
\hline AAPH: & $\begin{array}{l}2,2^{\prime} \text {-Azobis ( } 2 \text {-amidinopropane) } \\
\text { dihydrochloride }\end{array}$ \\
\hline ABTS: & 3-Ethylbenzothiazoline-6-sulphonic acid \\
\hline BAD: & Bcl-2-associated death promoter \\
\hline BAX: & BCL-2-associated X protein \\
\hline COX-2: & Cyclooxygenase 2 \\
\hline DHM: & Dihydromyricetin \\
\hline DPPH: & $\begin{array}{l}\text { 1,1-Diphenyl-2-picrylhydrazyl radical 2,2-diphe- } \\
\text { nyl-1-(2,4,6-trinitrophenyl) hydrazyl }\end{array}$ \\
\hline GSH: & Glutathione \\
\hline $\mathrm{H}_{2} \mathrm{O}_{2}:$ & Hydrogen peroxide \\
\hline HCC: & Hepatocellular carcinoma \\
\hline HUVECs: & Human umbilical vein endothelial cells \\
\hline iNOS: & Inducible nitric oxide synthase \\
\hline IL: & Interleukin \\
\hline $\mathrm{IC}_{50}:$ & Half-maximal inhibitory concentration \\
\hline LPO: & Lipid peroxidation \\
\hline LPS: & Lipopolysaccharide \\
\hline
\end{tabular}

MDA: Malondialdehyde

MIC: $\quad$ Minimum inhibitory concentration

MAPKs: Mitogen-activated protein kinases

MNU: 1-Methyl-1-nitrosourea

NF- $\kappa$ B: $\quad$ Nuclear factor- $\kappa$-gene binding

Nrf2: $\quad$ Nuclear factor erythroid 2-related factor 2

$\mathrm{O}_{2}{ }^{\bullet-}: \quad$ Superoxide anion

ORAC: Oxygen radical absorption capacity

$\mathrm{OH}^{\bullet}$ : $\quad$ Hydroxyl radicals

ROS: Reactive oxygen species

SOD: $\quad$ Superoxide dismutase

STAT3: $\quad$ Transduction and transcription 3

TNF- $\alpha$ : Tumor necrosis factor-alpha

TLRs: Toll-like receptors.

\section{Conflicts of Interest}

The authors declare that they have no conflicts of interest.

\section{References}

[1] W. Gao, S.-U. Lee, J. Li, and J.-W. Lee, "Development of improved process with treatment of cellulase for isolation of ampelopsin from dried fruits of Ampelopsis grossedentata," BioResources, vol. 11, no. 1, pp. 2712-2722, 2015.

[2] L. Weng, H. Zhang, X. Li et al., "Ampelopsin attenuates lipopolysaccharide-induced inflammatory response through the inhibition of the NF- $\kappa$ B and JAK2/STAT3 signaling pathways in microglia," International Immunopharmacology, vol. 44 , pp. 1-8, 2017.

[3] N. Jing and X. Li, "Dihydromyricetin attenuates inflammation through TLR4/NF-kappaB pathway," Open Medicine, vol. 14, no. 1, pp. 719-725, 2019.

[4] X. Hou, Q. Tong, W. Wang, W. Xiong, C. Shi, and J. Fang, "Dihydromyricetin protects endothelial cells from hydrogen peroxide-induced oxidative stress damage by regulating mitochondrial pathways," Life Sciences, vol. 130, pp. 38-46, 2015.

[5] K. Xie, X. He, K. Chen, J. Chen, K. Sakao, and D.-X. Hou, "Antioxidant properties of a traditional vine tea, Ampelopsis grossedentata," Antioxidants, vol. 8, no. 8, p. 295, 2019.

[6] J. Liu, Y. Shu, Q. Zhang et al., "Dihydromyricetin induces apoptosis and inhibits proliferation in hepatocellular carcinoma cells," Oncology Letters, vol. 8, no. 4, pp. 1645-1651, 2014.

[7] Y. Sun, W. Liu, C. Wang et al., "Combination of dihydromyricetin and ondansetron strengthens antiproliferative efficiency of adriamycin in K562/ADR through downregulation of SORCIN: a new strategy of inhibiting P-glycoprotein," Journal of Cellular Physiology, vol. 234, no. 4, pp. 3685-3696, 2019.

[8] L. Chen, M. Yao, X. Fan et al., "Dihydromyricetin attenuates streptozotocin-induced liver injury and inflammation in rats via regulation of NF- $\kappa$ B and AMPK signaling pathway," $e$ Food, vol. 1 , no. 2, pp. 188-195, 2020.

[9] J. He, J. Zhang, L. Dong et al., "Dihydromyricetin attenuates metabolic syndrome and improves insulin sensitivity by upregulating insulin receptor substrate-1 (Y612) tyrosine phosphorylation in $\mathrm{db} / \mathrm{db}$ mice," Diabetes, Metabolic Syndrome and Obesity: Targets and Therapy, vol. 12, pp. 22372249, 2019.

[10] L. Ran, X. L. Wang, H. D. Lang et al., “Ampelopsis grossedentata supplementation effectively ameliorates the glycemic 
control in patients with type 2 diabetes mellitus," European Journal of Clinical Nutrition, vol. 73, no. 5, pp. 776-782, 2019.

[11] T. T. Liu, Y. Zeng, K. Tang, X. M. Chen, W. Zhang, and X. Le $\mathrm{Xu}$, "Dihydromyricetin ameliorates atherosclerosis in LDL receptor deficient mice," Atherosclerosis, vol. 262, pp. 39-50, 2017.

[12] Y. Zeng, Y. Peng, K. Tang et al., "Dihydromyricetin ameliorates foam cell formation via LXR $\alpha$ - ABCA1/ABCG1-dependent cholesterol efflux in macrophages," Biomedicine \& Pharmacotherapy, vol. 101, pp. 543-552, 2018.

[13] Y. Chen, H.-Q. Luo, L.-L. Sun et al., "Dihydromyricetin attenuates myocardial hypertrophy induced by transverse aortic constriction via oxidative stress inhibition and SIRT3 pathway enhancement," International Journal of Molecular Sciences, vol. 19, no. 9, article 2592, 2018.

[14] L. Wei, X. Sun, X. Qi, Y. Zhang, Y. Li, and Y. Xu, "Dihydromyricetin ameliorates cardiac ischemia/reperfusion injury through Sirt3 activation," BioMed Research International, vol. 2019, Article ID 6803943, 9 pages, 2019.

[15] Z. Zhong, G. Zhou, and X. Chen, "The rat chronic toxicity test of total flavone of Ampelopsis grossedentata from Guangxi," Lishizhen Medicine \& Materia Medical Research, vol. 14, no. 4, pp. 193-195, 2003.

[16] J. J. Xu, M. J. Yao, and M. C. Wu, "Study on biological efficacy of dihydromyricetin," Food Science, vol. 29, pp. 622-625, 2008.

[17] L. Zhao, A. Wang, B. Liu, G. Li, Z. Zhang, and S. Chen, "Antioxidant and cytotoxic activity of dihydromyricetin from Ampelopsis grossedentata leaves," Agro Food Industry Hi-Tech, vol. 20, no. 3, pp. 14-17, 2009.

[18] D. Liu, Y. Mao, L. Ding, and X.-A. Zeng, "Dihydromyricetin: a review on identification and quantification methods, biological activities, chemical stability, metabolism and approaches to enhance its bioavailability," Trends in Food Science \& Technology, vol. 91, pp. 586-597, 2019.

[19] M. Wu, M. Jiang, T. Dong et al., "Reversal effect of dihydromyricetin on multiple drug resistance in SGC7901/5-FU cells," Asian Pacific Journal of Cancer Prevention, vol. 21, no. 5, pp. 1269-1274, 2020.

[20] R. Wang, J. Pi, X. Su et al., "Dihydromyricetin suppresses inflammatory responses in vitro and in vivo through inhibition of IKK $\beta$ activity in macrophages," Scanning, vol. 38, no. 6, p. 912, 2016.

[21] X. Hou, T. Wang, H. Ahmad, and Z. Xu, "Ameliorative effect of ampelopsin on LPS-induced acute phase response in piglets," Journal of Functional Foods, vol. 35, pp. 489-498, 2017.

[22] D. Xiang, L. Fan, X. L. Hou et al., "Uptake and transport mechanism of dihydromyricetin across human intestinal Caco-2 cells," Journal of Food Science, vol. 83, no. 7, pp. 1941-1947, 2018.

[23] H. Li, Q. Li, Z. Liu et al., "The versatile effects of dihydromyricetin in health," Evidence-based Complementary and Alternative Medicine, vol. 2017, Article ID 1053617, 10 pages, 2017.

[24] H. Tong, X. Zhang, L. Tan, R. Jin, S. Huang, and X. Li, “Multitarget and promising role of dihydromyricetin in the treatment of metabolic diseases," European Journal of Pharmacology, vol. 870, article 172888, 2020.

[25] K. Nurgali, R. T. Jagoe, and R. Abalo, "Adverse effects of cancer chemotherapy: Anything new to improve tolerance and reduce sequelae?," Frontiers in Pharmacology, vol. 9, p. $245,2018$.
[26] D. F. Romagnolo and O. I. Selmin, "Flavonoids and cancer prevention: a review of the evidence," Journal of Nutrition in Gerontology and Geriatrics, vol. 31, no. 3, pp. 206-238, 2012.

[27] F. Ni, Y. Gong, L. Li, H. M. Abdolmaleky, and J.-R. Zhou, "Flavonoid ampelopsin inhibits the growth and metastasis of prostate cancer in vitro and in mice," PLoS One, vol. 7, no. 6, article e38802, 2012.

[28] Y. Zhou, F. Shu, X. Liang et al., "Ampelopsin induces cell growth inhibition and apoptosis in breast cancer cells through ROS generation and endoplasmic reticulum stress pathway," PLoS One, vol. 9, no. 2, article e89021, 2014.

[29] Q. Y. Zhang, R. Li, G. F. Zeng et al., "Dihydromyricetin inhibits migration and invasion of hepatoma cells through regulation of MMP-9 expression," World Journal of Gastroenterology, vol. 20, no. 29, pp. 10082-10093, 2014.

[30] J. Xia, S. Guo, T. Fang et al., "Dihydromyricetin induces autophagy in HepG2 cells involved in inhibition of mTOR and regulating its upstream pathways," Food and Chemical Toxicology, vol. 66, pp. 7-13, 2014.

[31] H. Chang, X. Peng, Q. Bai et al., “Ampelopsin suppresses breast carcinogenesis by inhibiting the mTOR signalling pathway," Carcinogenesis, vol. 35, no. 8, pp. 1847-1854, 2014.

[32] S. Qi, X. Kou, J. Lv, Z. Qi, and L. Yan, “Ampelopsin induces apoptosis in HepG2 human hepatoma cell line through extrinsic and intrinsic pathways: involvement of P38 and ERK," Environmental Toxicology and Pharmacology, vol. 40, no. 3, pp. 847-854, 2015.

[33] X.-M. Chen, X.-B. Xie, Q. Zhao et al., “Ampelopsin induces apoptosis by regulating multiple c-Myc/S-phase kinaseassociated protein $2 / \mathrm{F}-$ box and WD repeat-containing protein 7/histone deacetylase 2 pathways in human lung adenocarcinoma cells," Molecular Medicine Reports, vol. 11, no. 1, pp. 105-112, 2015.

[34] S.-J. Kao, W.-J. Lee, J.-H. Chang et al., "Suppression of reactive oxygen species-mediated ERK and JNK activation sensitizes dihydromyricetin-induced mitochondrial apoptosis in human non-small cell lung cancer," Environmental Toxicology, vol. 32, no. 4, pp. 1426-1438, 2017.

[35] Z. Zhang, H. Zhang, S. Chen et al., "Dihydromyricetin induces mitochondria-mediated apoptosis in HepG2 cells through down-regulation of the Akt/Bad pathway," Nutrition Research, vol. 38, pp. 27-33, 2017.

[36] Y. Zuo, Q. Xu, Y. Lu et al., "Dihydromyricetin induces apoptosis in a human choriocarcinoma cell line," Oncology Letters, vol. 16, no. 4, pp. 4229-4234, 2018.

[37] Z. Guo, H. Guozhang, H. Wang, Z. Li, and N. Liu, “Ampelopsin inhibits human glioma through inducing apoptosis and autophagy dependent on ROS generation and JNK pathway," Biomedicine \& Pharmacotherapy, vol. 116, article 108524, 2019.

[38] F. Wang, X. Chen, D. Yuan, Y. Yi, and Y. Luo, "Golgi reassembly and stacking protein 65 downregulation is required for the anti-cancer effect of dihydromyricetin on human ovarian cancer cells," PLoS One, vol. 14, no. 11, article e0225450, 2019.

[39] Y. Zuo, Y. Lu, Q. Xu et al., "Inhibitory effect of dihydromyricetin on the proliferation of JAR cells and its mechanism of action," Oncology Letters, vol. 20, no. 1, pp. 357-363, 2020.

[40] B. Zhang, S. Dong, X. Cen et al., "Ampelopsin sodium exhibits antitumor effects against bladder carcinoma in orthotopic xenograft models," Anti-Cancer Drugs, vol. 23, no. 6, pp. 590-596, 2012. 
[41] J. Liang, J. Wu, F. Wang, P. Zhang, and X. Zhang, "Semaphoring $4 \mathrm{D}$ is required for the induction of antioxidant stress and anti- inflammatory effects of dihydromyricetin in colon cancer," International Immunopharmacology, vol. 67, pp. 220230, 2019.

[42] Z. Zhao, J.-q. Yin, M.-s. Wu et al., "Dihydromyricetin activates AMP-activated protein kinase and P38MAPKExerting antitumor potential in osteosarcoma," Cancer Prevention Research, vol. 7, no. 9, pp. 927-938, 2014.

[43] S.-W. Hong, N.-S. Park, M. H. Noh et al., "Combination treatment with erlotinib and ampelopsin overcomes erlotinib resistance in NSCLC cells via the Nox2-ROS-Bim pathway," Lung Cancer, vol. 106, pp. 115-124, 2017.

[44] P. Cheng, C. Gui, J. Huang et al., "Molecular mechanisms of ampelopsin from Ampelopsis megalophylla induces apoptosis in HeLa cells," Oncology Letters, vol. 14, no. 3, pp. 26912698, 2017.

[45] D.-Z. Zhou, H. Y. Sun, J. Q. Yue, Y. Peng, Y. M. Chen, and Z. J. Zhong, "Dihydromyricetin induces apoptosis and cytoprotective autophagy through ROS-NF- $\kappa \mathrm{B}$ signalling in human melanoma cells," Free Radical Research, vol. 51, no. 5, pp. 517-528, 2017.

[46] Y. Xu, S. Wang, H. F. Chan et al., "Dihydromyricetin induces apoptosis and reverses drug resistance in ovarian cancer cells by p53-mediated downregulation of survivin," Scientific Reports, vol. 7, no. 1, article 46060, 2017.

[47] B. Liu, X. Tan, J. Liang et al., "A reduction in reactive oxygen species contributes to dihydromyricetin- induced apoptosis in human hepatocellular carcinoma cells," Scientific Reports, vol. 4, no. 1, pp. 1-8, 2014.

[48] H. Huang, M. Hu, R. Zhao, P. Li, and M. Li, "Dihydromyricetin suppresses the proliferation of hepatocellular carcinoma cells by inducing G2/M arrest through the Chk1/Chk2/Cdc25C pathway," Oncology Reports, vol. 30, no. 5, pp. 2467-2475, 2013.

[49] G. Zeng, J. Liu, H. Chen et al., "Dihydromyricetin induces cell cycle arrest and apoptosis in melanoma SK-MEL-28 cells," Oncology Reports, vol. 31, no. 6, pp. 2713-2719, 2014.

[50] Z. Zhao, J. Q. Yin, M. S. Wu et al., "Dihydromyricetin activates AMP-activated protein kinase and P38MAPK exerting antitumor potential in osteosarcoma," Cancer Prevention Research, vol. 7, no. 9, pp. 927-938, 2014.

[51] L. Jiang, Q. Zhang, H. Ren et al., "Dihydromyricetin enhances the chemo-sensitivity of nedaplatin via regulation of the p53/Bcl-2 pathway in hepatocellular carcinoma cells," PLoS One, vol. 10, no. 4, article e0124994, 2015.

[52] E. Birben, U. M. Sahiner, C. Sackesen, S. Erzurum, and O. Kalayci, "Oxidative stress and antioxidant defense," World Allergy Organization Journal, vol. 5, no. 1, pp. 9-19, 2012.

[53] I. Liguori, G. Russo, F. Curcio et al., "Oxidative stress, aging, and diseases," Clinical Interventions in Aging, vol. 13, pp. 757-772, 2018.

[54] A. N. Panche, A. D. Diwan, and S. R. Chandra, "Flavonoids: an overview," Journal of Nutritional Science, vol. 5, 2016.

[55] X. Hou, J. Zhang, H. Ahmad, H. Zhang, Z. Xu, and T. Wang, "Evaluation of antioxidant activities of ampelopsin and its protective effect in lipopolysaccharide-induced oxidative stress piglets," PLoS One, vol. 9, no. 9, article e108314, 2014.

[56] W. Liao, Z. Ning, L. Ma et al., "Recrystallization of dihydromyricetin from Ampelopsis grossedentata and its anti-oxidant activity evaluation," Rejuvenation Research, vol. 17, no. 5, pp. 422-429, 2014.
[57] X. J. Zheng, H. Xiao, Z. Zeng et al., "Composition and serum antioxidation of the main flavonoids from fermented vine tea (Ampelopsis grossedentata)," Journal of Functional Foods, vol. 9, pp. 290-294, 2014.

[58] X. Li, J. Liu, J. Lin et al., "Protective effects of dihydromyricetin against ${ }^{\bullet} \mathrm{OH}$-induced mesenchymal stem cells damage and mechanistic chemistry,” Molecules, vol. 21, no. 5, p. 604, 2016.

[59] J. Ye, Y. Guan, S. Zeng, and D. Liu, “Ampelopsin prevents apoptosis induced by $\mathrm{H}_{2} \mathrm{O}_{2}$ in MT-4 lymphocytes," Planta Medica, vol. 74, no. 3, pp. 252-257, 2008.

[60] Y. Wu, Y. Xiao, Y. Yue, K. Zhong, Y. Zhao, and H. Gao, “A deep insight into mechanism for inclusion of $2 R, 3 R$-dihydromyricetin with cyclodextrins and the effect of complexation on antioxidant and lipid- lowering activities," Food Hydrocolloids, vol. 103, article 105718, 2020.

[61] G.-Y. Tan, M.-H. Zhang, J.-H. Feng, A.-Y. Han, S.-S. Zheng, and P. Xie, "Effects of pretreatment by the flavanol ampelopsin on porcine kidney epithelial cell injury induced by hydrogen peroxide," Agricultural Sciences in China, vol. 9, no. 4, pp. 598-604, 2010.

[62] X. Kou and N. Chen, "Pharmacological potential of ampelopsin in Rattan tea," Food Science and Human Wellness, vol. 1, no. 1, pp. 14-18, 2012.

[63] B. Jiang, L. Le, H. Pan, K. Hu, L. Xu, and P. Xiao, "Dihydromyricetin ameliorates the oxidative stress response induced by methylglyoxal via the AMPK/GLUT4 signaling pathway in PC12 cells," Brain Research Bulletin, vol. 109, pp. 117-126, 2014.

[64] X. Zhang, X. Li, J. Fang et al., “(2R,3R)Dihydromyricetin inhibits osteoclastogenesis and bone loss through scavenging LPS-induced oxidative stress and NF- $\kappa \mathrm{B}$ and MAPKs pathways activating," Journal of Cellular Biochemistry, vol. 119, no. 11, pp. 8981-8995, 2018.

[65] X. Zhang, L. Wang, L. Peng et al., "Dihydromyricetin protects HUVECs of oxidative damage induced by sodium nitroprusside through activating PI3K/Akt/FoxO3a signalling pathway," Journal of Cellular and Molecular Medicine, vol. 23, no. 7, pp. 4829-4838, 2019.

[66] C. Dong, G. Wu, H. Li, Y. Qiao, and S. Gao, “Ampelopsin inhibits high glucose-induced extracellular matrix accumulation and oxidative stress in mesangial cells through activating the Nrf2/HO-1 pathway," Phytotherapy Research, vol. 34, no. 8, pp. 2044-2052, 2020.

[67] H. Han, Y. Dong, and X. Ma, "Dihydromyricetin protects against gentamicin-induced ototoxicity via PGC- $1 \alpha /$ SIRT3 signaling in vitro," Frontiers in Cell and Developmental Biology, vol. 8, p. 702, 2020.

[68] B. Wu, J. Lin, J. Luo et al., "Dihydromyricetin Protects against Diabetic Cardiomyopathy in Streptozotocin- Induced Diabetic Mice," BioMed Research International, vol. 2017, Article ID 3764370, 13 pages, 2017.

[69] H. Li, F. Yu, X. Sun, L. Xu, J. Miu, and P. Xiao, "Dihydromyricetin ameliorates memory impairment induced by acute sleep deprivation," European Journal of Pharmacology, vol. 853, pp. 220-228, 2019.

[70] Y. Chang, L. Yuan, J. Liu et al., "Dihydromyricetin attenuates Escherichia coli lipopolysaccharide-induced ileum injury in chickens by inhibiting NLRP3 inflammasome and TLR4/NF$\kappa \mathrm{B}$ signalling pathway," Veterinary Research, vol. 51, no. 1 , p. 72,2020

[71] X. Liang, T. Zhang, L. Shi et al., "Ampelopsin protects endothelial cells from hyperglycemia-induced oxidative damage 
by inducing autophagy via the AMPK signaling pathway," BioFactors, vol. 41, no. 6, pp. 463-475, 2015.

[72] L. Liu, S. Sun, H. Rui, and X. Li, "In vitro inhibitory effects of dihydromyricetin on human liver cytochrome P450 enzymes," Pharmaceutical Biology, vol. 55, no. 1, pp. 1868-1874, 2017.

[73] M. Bebová, Z. Boštíková, M. Moserová et al., "Modulation of xenobiotic conjugation enzymes by dihydromyricetin in rats," Monatshefte für Chemie - Chemical Monthly, vol. 148, no. 11, pp. 2003-2009, 2017.

[74] L. Guo, H. Zhang, and X. Yan, "Protective effect of dihydromyricetin revents fatty liver through nuclear factor$\kappa \mathrm{B} / \mathrm{p} 53 / \mathrm{B}$-cell lymphoma 2 -associated $\mathrm{X}$ protein signaling pathways in a rat model," Molecular Medicine Reports, vol. 19, no. 3, pp. 1638-1644, 2019.

[75] F. Wu, Y. Li, H. Song et al., "Preventive effect of dihydromyricetin against cisplatin-induced nephrotoxicity in vitro and in vivo," Evidence-based Complementary and Alternative Medicine, vol. 2016, Article ID 7937385, 9 pages, 2016.

[76] L. Chen, H. Deng, H. Cui et al., "Inflammatory responses and inflammation-associated diseases in organs," Oncotarget, vol. 9, no. 6, pp. 7204-7218, 2018.

[77] J. Zhong and G. Shi, "Editorial: Regulation of inflammation in chronic disease," Frontiers in Immunology, vol. 10, p. 737, 2019.

[78] S. J. Maleki, J. F. Crespo, and B. Cabanillas, "Anti-inflammatory effects of flavonoids," Food Chemistry, vol. 299, article 125124, 2019.

[79] B. Wang, Y. Xiao, X. Yang et al., "Protective effect of dihydromyricetin on LPS-induced acute lung injury," Journal of Leukocyte Biology, vol. 103, no. 6, pp. 1241-1249, 2018.

[80] J. Wu, K.-J. Fan, Q.-S. Wang, B.-X. Xu, Q. Cai, and T.Y. Wang, "DMY protects the knee joints of rats with collagen-induced arthritis by inhibition of NF- $\kappa \mathrm{B}$ signaling and osteoclastic bone resorption," Food \& Function, vol. 11, no. 7, pp. 6251-6264, 2020.

[81] Z. Ren, P. Yan, L. Zhu et al., "Dihydromyricetin exerts a rapid antidepressant-like effect in association with enhancement of BDNF expression and inhibition of neuroinflammation," Psychopharmacology, vol. 235, no. 1, pp. 233-244, 2018.

[82] J. Feng, J.-. X. Wang, Y.-. H. Du et al., "Dihydromyricetin inhibits microglial activation and neuroinflammation by suppressing NLRP 3 inflammasome activation in APP/PS 1 transgenic mice," CNS Neuroscience \& Therapeutics, vol. 24, no. 12, pp. 1207-1218, 2018.

[83] B. Xu, S. Huang, C. Wang, H. Zhang, S. Fang, and Y. Zhang, "Anti-inflammatory effects of dihydromyricetin in a mouse model of asthma," Molecular Medicine Reports, vol. 15, no. 6, pp. 3674-3680, 2017.

[84] Z. Sun, W. Lu, N. Lin et al., "Dihydromyricetin alleviates doxorubicin-induced cardiotoxicity by inhibiting NLRP3 inflammasome through activation of SIRT1," Biochemical Pharmacology, vol. 175, article 113888, 2020.

[85] J. Wu, F.-T. Zhao, K.-J. Fan et al., "Dihydromyricetin inhibits inflammation of fibroblast-like synoviocytes through regulation of nuclear factor- $\kappa \mathrm{b}$ signaling in rats with collageninduced arthritis," Journal of Pharmacology and Experimental Therapeutics, vol. 368, no. 2, pp. 218-228, 2019.

[86] J. Chu, X. Wang, H. Bi, L. Li, M. Ren, and J. Wang, "Dihydromyricetin relieves rheumatoid arthritis symptoms and suppresses expression of pro-inflammatory cytokines _via_ the activation of Nrf2 pathway in rheumatoid arthritis model,"
International Immunopharmacology, vol. 59, pp. 174-180, 2018.

[87] S. Chen, X. Zhao, J. Wan et al., "Dihydromyricetin improves glucose and lipid metabolism and exerts anti- inflammatory effects in nonalcoholic fatty liver disease: A randomized controlled trial," Pharmacological Research, vol. 99, pp. 74-81, 2015.

[88] J. van Duynhoven, E. E. Vaughan, D. M. Jacobs et al., "Metabolic fate of polyphenols in the human superorganism," Proceedings of the National Academy of Sciences, vol. 108, Supplement 1, pp. 4531-4538, 2011.

[89] Q. Tong, X. Hou, J. Fang et al., "Determination of dihydromyricetin in rat plasma by LC-MS/MS and its application to a pharmacokinetic study," Journal of Pharmaceutical and Biomedical Analysis, vol. 114, pp. 455-461, 2015.

[90] R. Liu, J. Hong, X. Xu et al., "Gut microbiome and serum metabolome alterations in obesity and after weight- loss intervention," Nature Medicine, vol. 23, no. 7, pp. 859-868, 2017.

[91] X.-H. Zhu, H.-D. Lang, X.-L. Wang et al., "Synergy between dihydromyricetin intervention and irinotecan chemotherapy delays the progression of colon cancer in mouse models," Food \& Function, vol. 10, no. 4, pp. 2040-2049, 2019.

[92] N. Iida, A. Dzutsev, C. A. Stewart et al., "Commensal bacteria control cancer response to therapy by modulating the tumor microenvironment," Science, vol. 342, no. 6161, pp. 967-970, 2013.

[93] L. Fan, X. Zhao, Q. Tong et al., "Interactions of dihydromyricetin, a flavonoid from vine tea (Ampelopsis grossedentata) with gut microbiota," Journal of Food Science, vol. 83, no. 5, pp. 1444-1453, 2018. 